\title{
ДЕМОГРАФИЧЕСКАЯ МОДЕРНИЗАЦИЯ И ВОЗРАСТ ВСТУПЛЕНИЯ В ПЕРВЫЙ БРАК У НАРОДОВ СЕВЕРНОГО КАВКАЗА
}

\author{
КОНСТАНТИН КАЗЕНИН, ЕВГЕНИЙ СОРОКО
}

\begin{abstract}
Цель статьи - исследование изменений возрастных характеристик брачности у народов ряда регионов Северного Кавказа во второй половине XX-начале XXI века. Эта динамика исследуется 8 аспекте межэтнических различий. Делается попытка оценить уровень межэтнических различий на разных этапах модернизационных изменений, которые происходили в местных соииумах Северного Кавказа в 1960-2000-е годы и были связаны в первую очередь с массовой миграцией коренных народов в города. Для этого на основе микропереписи 1994 г. для женских и мужских когорт 1939-48, 194958 и 1959-68 годов рождения 11 северокавказских народов сопоставляются доли вступивших в первый брак к разным возрастам. Отмечается, что к возрастам, достигнутыл двумя или тремя из этих когорт на момент микропереписи, в разных когортах наблюдались в иелом единообразные межэтнические контрасты по этому параметру. Далее для тех же народов рассматриваются доли вступивших в брак в разных возрастных группах по Всероссийской переписи населения 20102. Межэтнические различия, зафиксированные для разных возрастных групп на момент переписи, в основном совпадают с различиями, отраженными микропереписью для указанных когорт. При этом сопоставление расчетных возрастов вступления в брак (SMAM) для разных народов на момент микропереписи 1994 г. и переписи 2010 г. показывает, что по крайней мере между этими опросами у большинства этносов происходил сдвиг вступления женщин и мужчин в первый брак к более стариим возрастам. Делается вывод, что из двух прочессов, стандартно рассматриваемых как элементы демографической модернизации (увеличение возраста вступления в первый брак и уменьшение межэтнических различий по этому возрасту), на Северном Кавказе в изучаемый период активно шел только первый. С учетом данных полевых исследований предлагаются объяснения обнаруженной стабильности межэтнических различий по возрасту вступления в брак.
\end{abstract}

Ключевые слова: возраст вступления в брак, когортный анализ, Северный Кавказ, модернизация, межэтнические различия.

\section{ВВЕДЕНИЕ}

Цель статьи - исследование динамики возрастных характеристик брачности у народов Северного Кавказа во второй половине XX - начале XXI века. Ключевой вопрос, который будет интересовать нас при рассмотрении этой динамики, касается межэтнических различий. Сопоставляя данные источников официальной статистики, мы покажем, что в первые постсоветские десятилетия у коренных народов Северного Кавказа в целом сохранялись те же межэтнические различия по возрасту вступления в первый брак, которые наблюдались между представителями тех же этносов, родившимися в середине XX века.

КОНСТАНТИН ИГОРЕВИЧ КАЗЕНИН (kz@ranepa.ru), РОССИЙСКАЯ АКАДЕМИЯ НАРОДНОГО ХОЗЯЙСТВА И ГОСУДАРСТВЕННОЙ СЛУЖБЫ ПРИ ПРЕЗИДЕНТЕ РОССИЙСКОЙ ФЕДЕРАЦИИ, РОССИЯ.

ЕВГЕНИЙ ЛЬВОВИЧ СОРОКО (esoroko@hse.ru), НАЦИОНАЛЬНЫЙ ИССЛЕДОВАТЕЛЬСКИЙ УНИВЕРСИТЕТ «ВЫСШАЯ ШКОЛА ЭКОНОМИКИ», РосСИЯ.

СТАТЬЯ ОТРАЖАЕТ РЕЗУЛЬТАТЫ ИССЛЕДОВАНИЙ, ПРОВЕДЕННЫХ К.И. КАЗЕНИНЫМ В РАМКАХ НИР ГОСУДАРСТВЕННОГО ЗАДАНИЯ РАНХИГС И Е.Л. СОРОКО В РАМКАХ ПРОГРАММЫ ФУНДАМЕНТАЛЬНЫХ ИССЛЕДОВАНИЙ НИУ ВШЭ.

СТАТЬЯ ПОСТУПИЛА В РЕДАКЦИЮ В ФЕВРАЛЕ 2021 Г. 
Обращение к вопросу о стабильности межэтнических различий по возрасту брачности на Северном Кавказе оправдано по нескольким причинам.

Северный Кавказ последних десятилетий - яркий пример многонационального региона, в котором интенсивно идут процессы социальной модернизации. Они связаны прежде всего с миграцией сельского населения в города, активная фаза которой пришлась в северокавказских республиках на разные периоды, но во всех имела место позже, чем в Центральной России: например, в западной части Северного Кавказа - КабардиноБалкарии (КБР) и Карачаево-Черкесии (КЧР) - в 1950-1960-е годы (Белозеров 2005), а в Дагестане - в конце советского периода и в 1990-е годы (Карпов, Капустина 2011). Модернизационные процессы, связанные с урбанизацией и распадом традиционного уклада сельских сообществ, отразились в том числе и на семейных практиках: например, общей тенденцией в постсоветское время на Северном Кавказе стало ослабление традиционных гендерных асимметрий в организации семьи (Стародубровская 2019). Также в 1960-1990-е годы в республиках Северного Кавказа имели место стандартные для периода урбанизации демографические изменения, прежде всего - снижение рождаемости. Оно стартовало по регионам не синхронно, но к 2000 г. привело рождаемость к уровню простого воспроизводства или даже более низкому уровню во всех регионах СевероКавказского федерального округа, кроме Чечни и Ингушетии (Казенин, Козлов 2016). Снижение рождаемости в контексте массового переселения в города соответствовало «классической» картине первого демографического перехода, существенного этапа демографической модернизации.

Одно из стандартных ожиданий, касающихся демографической модернизации, состоит в том, что в ее ходе ослабевают межэтнические различия по характеристикам брачности и рождаемости. Такое ожидание вполне соответствует представлениям о модернизирующемся обществе как о «плавильном котле», в котором представители разных народов оказываются перед лицом одних и тех же социальных перемен и под их действием отходят от устоявшихся норм демографического поведения, унаследованных от предков. Ряд эмпирических исследований подтверждает, что межэтническая «конвергенция» выражена более ярко именно тогда, когда из-за миграции в города или других процессов снижаются культурные различия между народами. Например, в (Yavuz 2004) продемонстрировано, что в Турции конца XX века наиболее значимые различия по рождаемости сохранялись между турками и той частью курдского (по самоидентификации) населения, которая сохраняла родной язык в домашнем общении; курды, перешедшие на турецкий язык, отличались по уровню рождаемости от турок в меньшей степени. Ослабление различий между коренным населением развитых стран мира и иностранными мигрантами в этих странах по характеристикам брачности и рождаемости, обычно особенно заметное для мигрантов второго поколения, также часто объясняется ослаблением культурных барьеров в условиях этнического смешения (Crul, Schneider, Lelie (eds.) 2012). Вместе с тем было бы недопустимым упрощением утверждать, что межэтническая «конвергенция» по брачности и рождаемости неизбежно имеет место в результате социальной модернизации. Межэтнические различия могут быть весьма устойчивыми в том числе и в странах, в которых первый демографический переход и соответствующие ему социальные изменения давно завершились. Например, хорошо известно, что в США весьма 
стабильными остаются различия по рождаемости между белым населением европейского происхождения и населением мексиканского происхождения (Parrado 2011).

На таком фоне Северный Кавказ представляет интерес прежде всего благодаря своей полиэтничности. Вопрос, сохраняются ли различия между разными народами по демографическому поведению в условиях социальной модернизации, применительно к этой части России можно рассматривать, сопоставляя демографические траектории большого числа этносов, в достаточно узких временных рамках оказавшихся перед лицом примерно одинаковых социальных изменений. Анализ данных большого числа этносов дает возможность увидеть разные варианты динамики межэтнических различий в условиях социальных изменений.

Имеется и другая причина, по которой народы Северного Кавказа представляют особый интерес для исследований по данной тематике. В исследованиях «традиционных» обществ, под которыми обычно понимаются общества с жесткими различиями гендерных ролей и значительной степенью зависимости младшего поколения от старшего, стандартным ожиданием является молодой возраст наступления демографических событий, связанных с переходом во взрослую жизнь, особенно вступления женщин в брак и рождения первого ребенка (см. (Mason 1987; Lerch 2013) о связи различных аспектов семейного «традиционализма» или «патриархальности» с характеристиками рождаемости). Однако в некоторых республиках Северного Кавказа данные полевых исследований свидетельствуют, что элементом традиционного семейного уклада может быть, наоборот, поздний (близкий к 25 годам) возраст вступления женщин в брак. Так, на основе опроса, проведенного в Карачаево-Черкесии в 2018 г. (Казенин 2019а), было показано, что на современном этапе у народа этой республики, отличающегося большей сохранностью традиционных семейных норм в сфере гендерных и межпоколенческих отношений (карачаевцев), наблюдается значимо более высокий возраст вступления женщин в брак по сравнению с другими народами региона. Полевые исследования, проведенные в Дагестане, при этом указывают на наличие по крайней мере у некоторых его народов стандартно ожидаемой связи семейного «традиционализма» с ранней брачностью и рождаемостью (Казенин, Козлов 2017). Такие полевые результаты позволяют предположить наличие на Северном Кавказе существенных межэтнических различий по брачно-репродуктивным траекториям до начала масштабной социальной модернизации. Если это предположение подтверждается на более широком материале, то интерес представляет судьба таких различий в процессе модернизационных изменений.

В настоящей статье предметом рассмотрения оказываются только возрастные характеристики брачности. Такой выбор обусловлен тем, что брачность в общем случае одна из наиболее жестко регламентированных сторон демографического поведения в обществах традиционного уклада, что не является исключением и для Северного Кавказа (Карпов 2001). При этом мы рассматриваем возрастные характеристики брачности как для женщин, так и для мужчин. Отметим, что в исследованиях обществ традиционного уклада и происходящих в них модернизационных процессов брачность мужчин в целом рассматривается реже, чем женщин. Однако одним из демографических проявлений жестких гендерных иерархий признается большой возрастной разрыв между мужем и 
женой (Gruber, Szołtysek 2012), вследствие чего параллельное исследование возраста вступления в первый брак женщин и мужчин представляет интерес.

В нашей работе мы сначала рассматриваем данные о возрасте вступления в первый брак женщин и мужчин когорт 1939-48, 1949-58, 1959-68 годов рождения (г.р.) у 11 этносов Северного Кавказа по данным микропереписи населения России 1994 г. (МП-94)1. Обнаруживается, что в этих десятилетних когортах как у женщин, так и у мужчин наблюдались заметные межэтнические различия по возрастному распределению первых браков, причем в возрастах, которых на момент микропереписи достигли 2 или 3 из указанных когорт, в разных когортах в основном повторялись одни и те же межэтнические различия. Также мы показываем, что в распределении респондентов 15-49 лет по брачному статусу на момент Всероссийской переписи населения 2010 г. (ВПН-2010) имеются межэтнические различия в основном такого же характера. Далее, сопоставляя расчетные возраста вступления в брак (SMAM) для различных этносов в выборке МП-94 (для всей выборки, а не отдельных когорт) и ВПН-2010, мы показываем, что между этими двумя опросами у большинства исследуемых этносов имел место сдвиг первых браков к более старшим возрастам как у женщин, так и у мужчин. Иными словами, из двух процессов, ожидаемых в контексте демографической модернизации («постарение» брачности и стирание межэтнических различий по ее возрастным характеристиками), в 1990-2000-е годы в рассматриваемых регионах первый был гораздо заметнее, чем второй. В заключительной части статьи обсуждаются возможные причины стабильности некоторых выявленных межэтнических различий, а также демонстрируется, какой интерес могут представлять полученные результаты для теории демографической модернизации.

\section{ДАННЫЕ И МЕТОД}

Прежде, чем ставить вопрос о сохранности межэтнических различий по матримониальному поведению в период постсоветских трансформаций, нам, очевидно, необходимо продемонстрировать, что такие различия существовали и были достаточно стабильными на определенном историческом этапе. МП-94 дает такую возможность. Одна из отличительных особенностей этого обследования, охватившего 5\% населения страны, состоит в том, что респондентам задавали вопросы о годе и месяце наступления различных демографических событий, включая вступление в первый брак. Ни Всесоюзные, ни Всероссийские переписи населения, ни российская микроперепись 2015 г. не включали такого вопроса о первом браке, т. е. МП-94 была для нас в этом отношении уникальным источником ${ }^{2}$.

\footnotetext{
${ }^{1}$ См. о ней (Пьянкова, Щербакова, Васин 2018).

2 Источником, позволяющим расширить хронологические рамки исследования, могла бы послужить микроперепись населения СССР 1985 г. (см. о ней также (Пьянкова, Щербакова, Васин 2018)), в анкету которой также был включен вопрос о возрасте вступления в брак и по данным которой были построены таблицы брачности для многих народов СССР (Дарский, Ильина 2000); о составе вопросов о брачном состоянии респондента в советских и российских переписях и микропереписях см. также (Захаров 2018: 99-106). К сожалению, микроданные этого масштабного опроса не доступны для исследователей.
} 
По данным МП-94 мы исследовали характеристики первой брачности для мужских и женских реальных когорт разных северокавказских народов следующих годов рождения: 1939-48, 1949-58, 1959-68. Объединение респондентов МП-94 в столь крупные (десятилетние) когорты по годам рождения было обусловлено соображениями статистической надежности, поскольку использование, например, пятилетних когорт по отдельным этносам давало бы слишком малые подвыборки респондентов. Сам же выбор когортной (а не периодной) «оптики» для анализа данных МП-94 представлялся предпочтительным, поскольку разные когорты, рожденные в советское время, очевидно отличались своим историческим опытом. Применительно к Северному Кавказу эти различия были связаны не только с событиями мирового и странового масштаба, но и, например, со сталинскими депортациями. У этносов, ставших жертвами этого преступления, когорты 1939-48 и 1949-58 г.р. в детстве самым непосредственным образом испытали на себе его последствия, тогда как представители наиболее молодой из трех наших когорт родились, когда возвращение из ссылки было в основном завершено. На таком фоне наличие регулярных межэтнических различий по брачности, повторяемых из когорты в когорту, может рассматриваться как достаточно сильное подтверждение устойчивых контрастов по матримониальному поведению, производных не от меняющегося социального контекста, а скорее от традиций и культурных норм этносов. Разумеется, для того, чтобы более определенно судить о наличии таких контрастов, имело бы смысл рассмотреть и брачность более ранних когорт. Однако численность респондентов когорт, родившихся в 1920-1930-е годы и ранее, в выборке МП-94 года заметно меньше, чем когорт, выбранных нами для исследования. Кроме того, с учетом времени проведения опроса при анализе данных более старших когорт вставала бы непростая проблема селективности респондентов по дожитию.

Для респондентов разных когорт в МП-94 вычислялась накопленная брачность к разным возрастам (отдельно для женщин и мужчин) как отношение респондентов, вступивших в первый брак до определенного возраста, ко всем респондентам когорты. Этот показатель определялся только для тех возрастов, которые на момент опроса были достигнуты всеми представителями соответствующей когорты. Выбор «границ» когорт по годам рождения позволяет оценить таким образом накопленную брачность у всех когорт к возрастам до 25 лет, для когорт 1939-48 и 1949-58 годов рождения - до 35 лет, у когорты 1939-48 годов рождения - до 45 лет (из-за крайней нераспространенности первых браков в возрасте 40+ на Северном Кавказе, для этой когорты приводятся данные для возрастов до 40 лет). В силу того, что МП-94 была выборочным опросом и на полиэтничном Северном Кавказе представленность в выборке разных народов была различной, в целом завися от их доли в общем населении региона, коэффициенты накопленной брачности вычислялись с доверительными интервалами на 95\%-ном уровне значимости. При обсуждении результатов во внимание принимались в первую очередь межэтнические различия, подтвержденные отсутствием «пересечения» доверительных интервалов.

Как уже было отмечено, проведенные после 1994 г. всеобщие переписи 2002, 2010 гг. и микроперепись 2015 г. не позволяли произвести по их данным аналогичный когортный анализ брачности. По существу, вся информация о возрасте вступления в брак, доступная на основе этих источников, состоит в распределении респондентов разных 
возрастов по брачному статусу на момент опроса, при этом остается неизвестным, в каком возрасте опрашиваемый перешел в свой текущий брачный статус (например, вступил в первый брак). Несмотря на это, переписи 2002 и 2010 г. и микроперепись 2015 г. остаются единственными источниками данных об этнических особенностях брачности в период после проведения МП-94 (как известно, текущая статистика Росстата не отражает этническую принадлежность вступающих в брак). Что касается выборочных опросов населения, то опросы, проведенные на Северном Кавказе, в основном далеки от пропорционального и достаточно «представительного» присутствия в их выборках всех этносов этого региона (особенно остра эта проблема в Дагестане). В качестве источника по «постсоветской» брачности мы использовали ВПН-2010. Отказ от использования микропереписи 2015 г., несмотря на то, что ее результаты отразили более длительный период после распада СССР, был связан с отмечаемыми в ряде исследований проблемами с составом ее выборки (Пьянкова, Щербакова, Васин 2018).

При сопоставлении двух источников мы исходили из того, что если межэтнические различия, засвидетельствованные у когорт 1939-1968 г.р. по МП-94, сохранились у более молодых когорт, находившихся в репродуктивном возрасте на момент ВПН-2010, то в распределении респондентов ВПН-2010 по брачному статусу будут наблюдаться контрасты, сходные с теми, которые обнаруживаются для указанных когорт. Например, если у этих когорт между какими-то этносами обнаружено значимое различие по доле вступивших в первый брак к 20 годам, то в случае сохранности этого различия в 1990-2000-е годы между этими же этносами ожидается аналогичный контраст по доле вступивших в первый брак среди 20-летних (см. ниже о некоторых методологических проблемах такого сопоставления) ${ }^{3}$.

Номенклатура этносов в ВПН-2010 несколько отличается от МП-94; в случае Северного Кавказа различия связаны с тем, что некоторые «субэтносы», в советское время в директивном порядке причислявшиеся к крупным народам региона, начиная с переписи 2002 г. получили возможность регистрироваться по самоназваниям. В целях сопоставления с МП-94 при анализе данных ВПН-2010 респонденты, идентифицировавшие себя как представители таких «субэтносов», были присоединены к респондентам тех народов, к которым эти «субэтносы» ранее официально причислялись ${ }^{4}$.

\footnotetext{
${ }^{3}$ В общем случае процесс изменения во времени каких-либо демографических характеристик, как хорошо известно, следует отслеживать либо для серии реальных когорт, либо для серии условных когорт (периодных «срезов» для календарных лет). В свете этого требования предложенное нами сопоставление не вполне корректно. Однако, как представляется, оно допускало интерпретацию в свете задач нашего исследовании: если мы предполагаем стабильность межэтнических различий по брачности от одной когорты к другой, то следует ожидать воспроизводства этих различий и в распределении по брачности на момент переписи, во время которой в репродуктивном возрасте находились исследуемые когорты.

${ }^{4}$ См. (Богоявленский 2012). В Дагестане при анализе данных ВПН-2010 к аварцам нами были по указанным причинам «присоединены» в расчетах андийцы, багвалинцы, бежтинцы, гинухцы, годоберинцы, гунзибцы, дидойцы, тиндинцы, чамалалы, хваршинцы (инхокваринцы), цезы; к даргинцам - кайтагцы, кубачинцы, мегебцы. Что касается черкесского населения, разделение которого на адыгейцев в Адыгее, черкесов в Карачаево-Черкесии и кабардинцев в Кабардино-Балкарии, принятое в советское время и сохраненное в МП-94, признается исследователями достаточно условным и не полностью соответствующим культурноисторическим реалиям (Тайсаев 2015), то мы сопоставляли респондентов из КБР, идентифицировавшихся
} 
И МП-94, и ВПН-2010 учитывали как зарегистрированные, так и незарегистрированные браки, при этом вопрос о годе и месяце вступления в первый брак в анкете МП-94 касался обоих видов брака (Захаров 2018: 104). Мы не различали зарегистрированные и незарегистрированные браки в наших расчетах (среди мужчин 15-59 лет, включенных в наше исследование народов, доля состоявших на момент МП-94 в незарегистрированном браке колебалась с $0,3 \%$ у табасаранцев до $8,4 \%$ у осетин, среди женщин тех же возрастов - с $0,2 \%$ у табасаранцев до $8,4 \%$ у осетин; в ВПН ни у одного из рассматриваемых здесь народов доля состоявших в незарегистрированном браке как у женщин, так и у мужчин не превышала $10 \%$ всех состоявших в браке). Также мы не различали в наших расчетах городское и сельское население. Такое решение было связано с тем, что в силу интенсивности миграционных потоков из села в город в позднее советское и постсоветское время многие респонденты МП-94 и ВПН-2010, опрошенные в городах Северного Кавказа, родились и прожили значительную часть жизни в селе, однако точно установить время переезда из села в город данные о «миграционных историях» респондентов этих двух опросов позволяют не всегда.

Мы включили в рассмотрение этносы, основным местом проживания которых являются четыре региона Северного Кавказа: Дагестан, Северная Осетия, КабардиноБалкария и Карачаево-Черкесия ${ }^{5}$. Исследовали наиболее крупные по численности неславянские этносы этих регионов. В Дагестане это 6 основных его народов - аварцы, даргинцы, кумыки, лакцы, лезгины и табасаранцы, в Северной Осетии - осетины, в Кабардино-Балкарии - кабардинцы и балкарцы, в Карачаево-Черкесии - карачаевцы, черкесы и абазины. Два последних народа рассматривали совместно, поскольку они являются близкородственными и характеризуются интенсивными межэтническими контактами. Для каждого этноса рассматривали только респондентов, проживающих в «родном» для этого этноса регионе. В таблице 1 приведена численность мужчин и женщин указанных народов, принадлежащих к исследуемым нами когортам, в выборке МП-94.

Таблица 1. Численность респондентов - представителей этносов, включенных в исследование, в выборке МП-94, по полу и когортам

\begin{tabular}{l|c|r|r|r|rrr}
\hline \multirow{2}{*}{ Этносы } & \multicolumn{2}{c|}{ 1939-48 г.р. } & \multicolumn{2}{c|}{ 1949-58 г.p. } & \multicolumn{2}{c}{$1959-68$ г.p. } \\
\cline { 2 - 7 } & мужчины & женщины & мужчины & женщины & мужчины & женщины \\
\hline Аварцы & 832 & 815 & 1447 & 1638 & 2156 & 2395 \\
Даргинцы & 430 & 465 & 769 & 884 & 1145 & 1241 \\
Кумыки & 432 & 469 & 759 & 860 & 955 & 1067 \\
Лакцы & 129 & 186 & 270 & 276 & 330 & 387 \\
Лезгины & 686 & 748 & 1410 & 1598 & 1884 & 1904 \\
Табасаранцы & 151 & 122 & 242 & 297 & 322 & 415 \\
Осетины & 863 & 1001 & 1185 & 1236 & 1646 & 1626 \\
Кабардинцы & 800 & 888 & 1143 & 1193 & 1690 & 1715 \\
Балкарцы & 130 & 126 & 252 & 302 & 337 & 281 \\
Карачаевцы & 252 & 299 & 485 & 503 & 623 & 761 \\
Черкесы и абазины & 140 & 162 & 245 & 235 & 309 & 269 \\
\hline
\end{tabular}

как кабардинцы и черкесы на ВПН-2010, с кабардинцами КБР из базы МП-94, а респондентов из КЧР, идентифицировавшихся под этими же двумя этнонимами на ВПН- 2010, с черкесами КЧР из базы МП-94. 5 Решение не включать в наш анализ чеченцев и ингушей связано с тем, что в Чеченской Республике МП-94 не проводилась, а качество ее данных по Республике Ингушетия вызывает сомнения в связи с крайне сложной обстановкой в этом регионе в 1994 г. 
Дополнительно по данным МП-94 для наиболее крупных этносов были вычислены по тем же когортам кумулятивные вероятности остаться никогда не состоявшим в браке к разным возрастам. Эти вероятности были посчитаны на основе составленных нами когортных таблиц брачности. Поскольку построение таких таблиц на основе ВПН-2010 невозможно, для исследования вопроса о сохранности межэтнических различий в постсоветское время эти показатели не использовались. Они служили только для более полной демонстрации тех межэтнических различий у когорт, которые были обнаружены с помощью коэффициентов накопленной брачности на основе данных МП-94.

Проводя сопоставление данных МП-94 и ВПН-2010, необходимо было учитывать ряд ограничений, вытекающих из методологии нашего анализа.

Во-первых, показатели, оценка которых была произведена на данных МП-94 и ВПН-2010, не вполне идентичны друг другу. По данным МП-94 мы сопоставляли этносы по накопленной брачности, охватывавшей жизненный отрезок до достижения некоторого возраста, а по данным ВПН-2010 - по доле вступивших в брак среди тех, кто на момент переписи был в соответствующем возрасте. Сопоставляя, например, накопленную к 25 годам брачность по МП-94 с долей вступивших в первый брак среди респондентов 25 лет по ВПН-2010, необходимо учитывать, что последние могли вступить в брак в том числе и уже в 25-летнем возрасте (в котором разные респонденты этой группы на момент переписи прожили разное число месяцев). Однако очевидно, что во многом доля вступивших в брак среди респондентов какого-либо возраста формируется за счет различий в брачном поведении в более молодых возрастах. Нам представляется возможным исходить из того, что межэтнические контрасты по накопленной брачности к определенному возрасту указывают и на различия по доле вступивших в брак среди респондентов того же возраста.

Во-вторых, данные МП-94 о накопленной брачности реальных когорт к разным возрастам могут быть искажены вследствие смертности и миграционных процессов. Например, доля женщин, вступивших в брак к 24 годам в когорте 1939-48 г.р., вычисленная по данным МП-94, характеризует, очевидно, только тех представительниц этой когорты, которые дожили до данного опроса и находились на его момент в своем родном регионе. Вычисленный показатель может отличаться от того, который учитывал бы всех женщин этой когорты, проживавших в своем регионе на момент достижения 24 лет, включая тех, кто впоследствии «выбыл» по разным причинам. При этом невозможно утверждать, что, например, по уровню смертности у женщин северокавказских народов в советское время не имелось межэтнических различий (в частности, естественно ожидать более высокую смертность у этносов, подвергшихся депортациям (Эдиев 2003)). Однако обозначенная проблема не представляется принципиальной для нашего анализа, поскольку нет какихлибо оснований полагать, что вероятность «выбытия» по причине смерти или миграции у изучаемых этносов как-либо коррелировала с возрастом вступления в брак.

Наконец, существенные ограничения связаны со степенью надежности данных ВПН-2010 для Северного Кавказа (о проблемах с данными этой переписи по северокавказским республикам см. (Андреев 2012; Мкртчян 2019)). Однако доступные нам результаты критического анализа ВПН-2010 не указывают на то, что ее данные содержат 
искажения, которые затронули бы только отдельные этносы и тем самым привели бы к смещению в оценке межэтнических контрастов.

Наряду с исследованием сохранности межэтнических различий в постсоветское время на основе тех же источников мы сделали попытку ответить и на вопрос, имело ли место у народов, включенных в исследование, изменение возрастной модели брачности в первые постсоветские десятилетия. С этой целью для всех этносов по выборкам МП-94 и ВПН-2010 были определены расчетные возраста вступления в брак (Singulate Mean Age at Marriage - SMAM (Hajnal 1953; United Nations 1990)). SMAМ является показателем возраста брачности, вычисление которого наиболее доступно по российским переписным данным. Его преимущество также в том, что в отличие от других возрастных показателей брачности значение SMAM не зависит от доли лиц, не вступивших в брак до конца репродуктивного возраста, т. е. отражает именно возрастные характеристики заключенных браков. Поскольку в данном случае нас интересовал вопрос о возрастных сдвигах в период между двумя обследованиями, по МП-94 мы вычисляли SMAM не для когорт, а для всех респондентов соответствующего этноса на основе их брачного статуса на момент опроса.

\section{РЕЗУЛЬТАТЫ ИССЛЕДОВАНИЯ}

На рисунке 1а-в показана накопленная брачность, рассчитанная по МП-94 для женских когорт. Можно видеть, что в когортах 1949-58 и 1959-68 г.р. значимость межэтнических различий в целом выше, чем в самой старшей когорте, что может объясняться меньшим числом респондентов, относящихся к последней. Ряд межэтнических контрастов при этом является общим для всех трех когорт. Так, среди дагестанских народов более низким уровнем накопленной брачности ко всем возрастам до 30 лет отличаются лакцы. К 30 годам (у когорт, достигших этого возраста на момент микропереписи) «отставание» лакцев от других дагестанских народов заметно сокращается. Значимо более ранней брачностью по сравнению с другими дагестанскими народами отличаются табасаранцы, однако этот контраст исчезает в когорте 1959-68 г.р. Среди четырех других дагестанских народов в молодых возрастах медленнее «накапливают» брачность кумыки, но к 25 годам их «отставание» теряет значимость. Что касается народов других северокавказских регионов, то наблюдается явный контраст между кабардинцами, черкесами и абазинами, с одной стороны, и балкарцами, карачаевцам и осетинами, с другой: первая группа народов во всех трех когортах отличается заметно более ранней брачностью, причем контрасты по накопленной брачности между народами двух групп частично сохраняют значимость и к 30 годам (у когорт, достигших этого возраста к МП-94). Накопленная брачность исследуемых когорт отражена также в таблицах П1-6 Приложения. 
A) $1939-1948$ г.p.

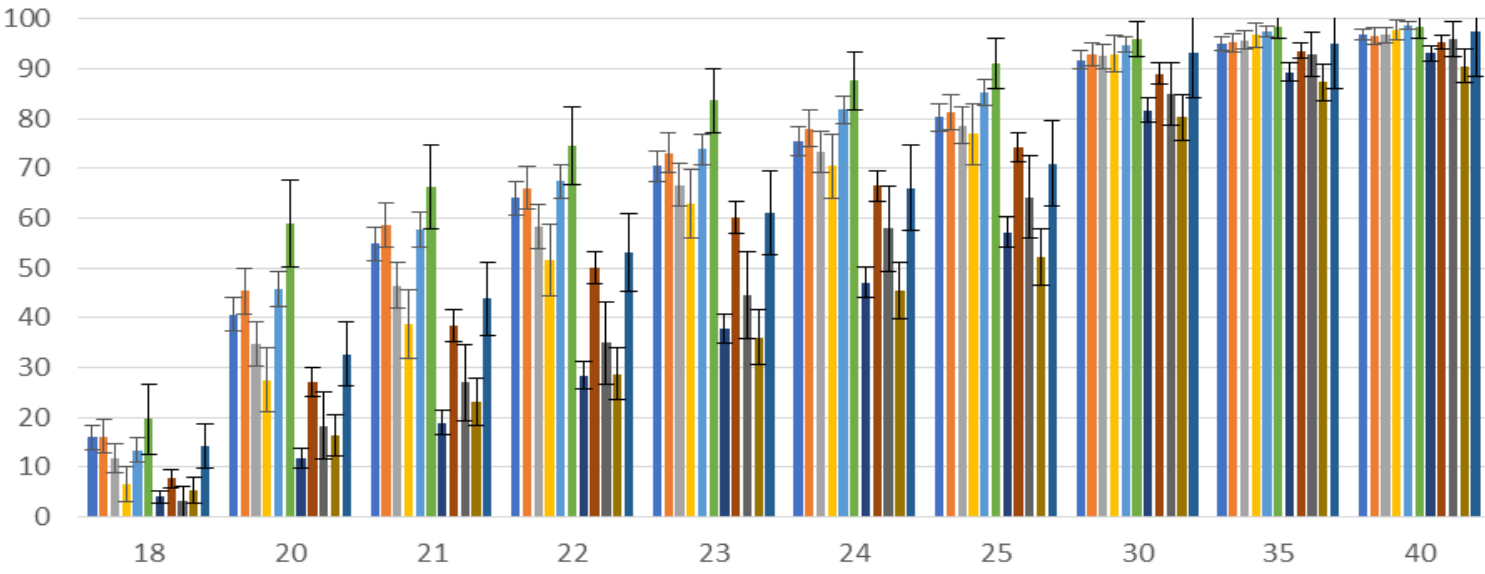

Б) $1949-1958$ г.p.
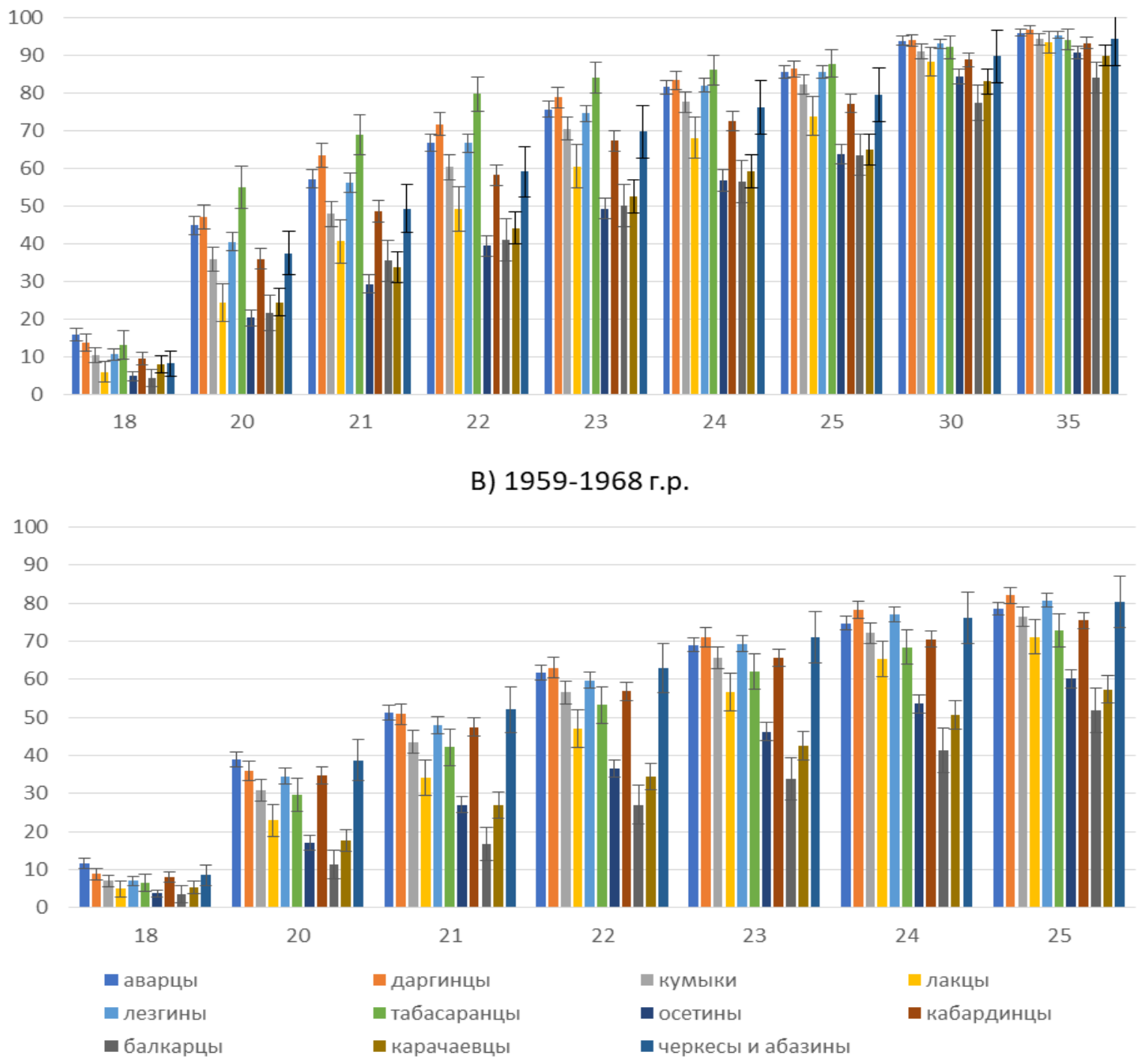

Рисунок 1. Накопленная брачность у женских когорт 1939-1968 г.р. по отдельным народам Северного Кавказа, доли вступивших в первый брак к разным возрастам, $\%$

Источник: Рассчитано авторами по данным МП-94. 
A) $1939-1948$ г.p.

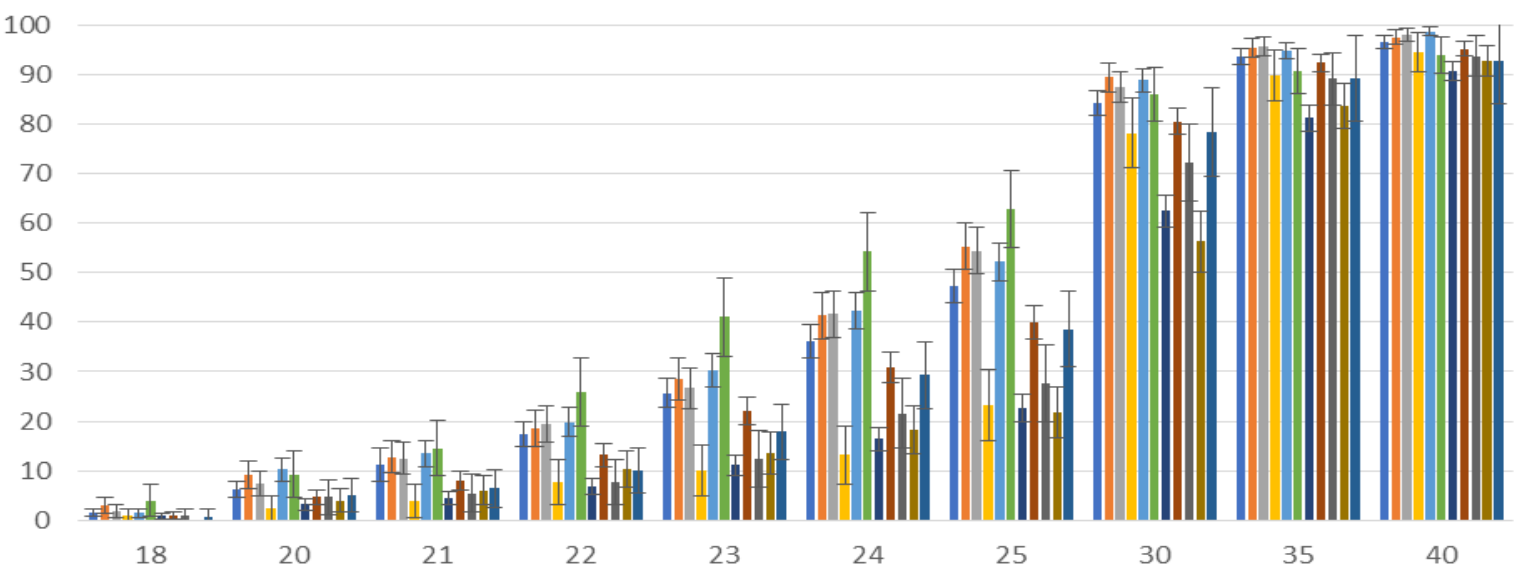

Б) $1949-1958$ г.p.

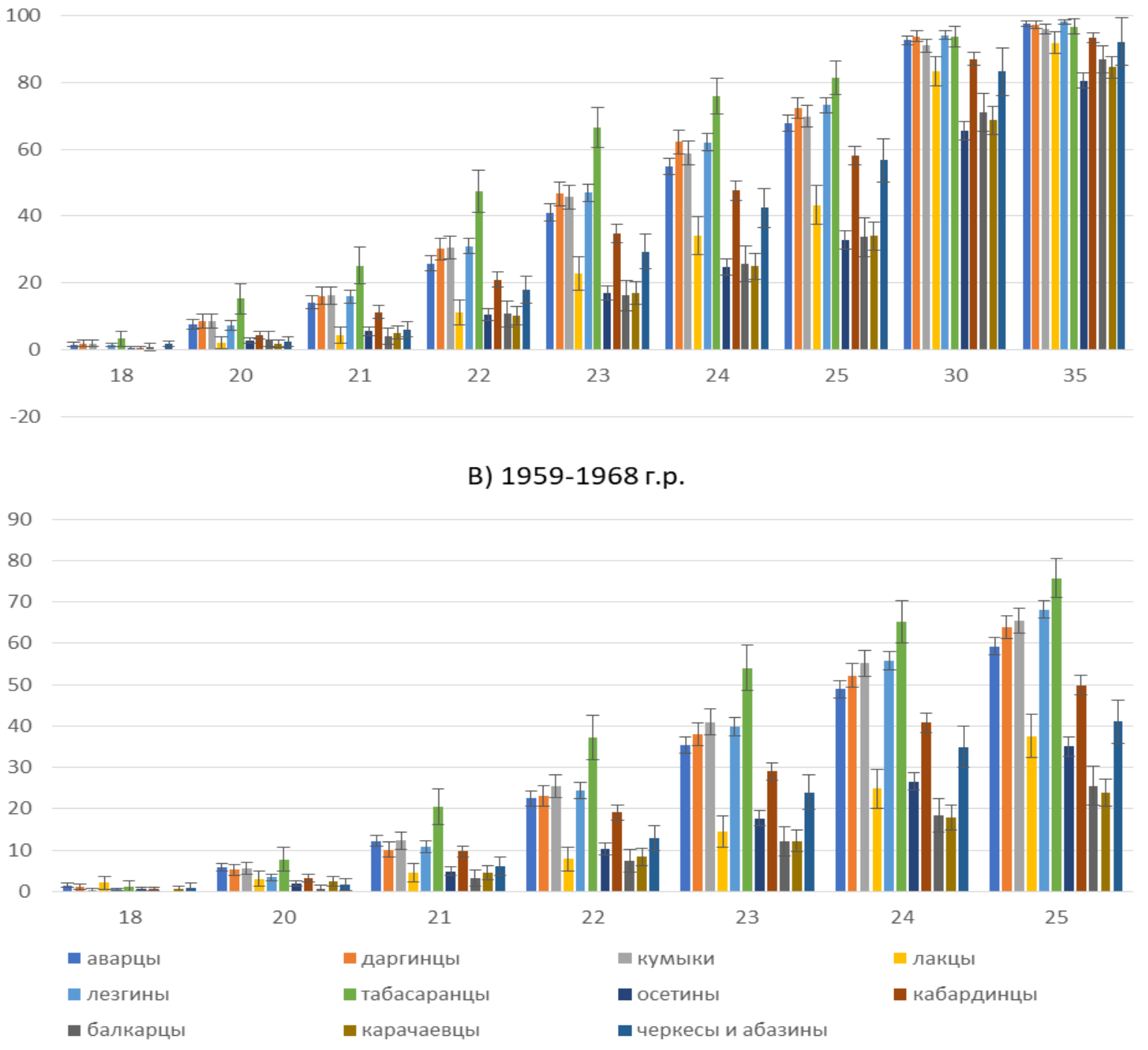

Рисунок 2. Накопленная брачность у мужских когорт 1939-1968 г.р. по отдельным этносам Северного Кавказа, доли вступивших в первый брак к разным возрастам, \%

Источник: Рассчитано авторами по данным МП-94. 
Обратимся теперь к накопленной брачности тех же когорт у мужчин (рисунок 2а-в). При явном отставании мужчин от женщин по доле вступивших в брак ко всем возрастам до 30 лет, характерном для всех этносов, межэтнические различия у мужчин в основном те же, что и у женщин. Так, среди дагестанских этносов «отставание» лакцев по накопленной брачности у мужчин даже заметнее, чем у женщин. Также заметна более ранняя брачность табасаранцев, причем у мужчин, в отличие от женщин, различия между табасаранцами и другими народами Дагестана сохраняют значимость и в когорте 1959-68 г.p. Значимых различий между кумыками, с одной стороны, и аварцами, даргинцами и лезгинами, с другой, у мужчин, в отличие от женщин, не наблюдалось. За пределами Дагестана у мужчин межэтнические контрасты в целом также подобны тем, что выявлены для женщин. При этом если среди женщин народы с более ранней брачностью (кабардинцы, черкесы и абазины) не имели значимых отличий от большинства народов Дагестана, то у мужчин эти народы значимо отстают от дагестанских (кроме лакцев) к возрастам до 25 лет включительно, также значимо опережая при этом осетин, карачаевцев и балкарцев.

Чтобы получить более детальное представление о межэтнических различиях по возрастным характеристикам брачности рассматриваемых когорт, мы также рассчитали кумулятивные вероятности не вступить в первый брак к разным возрастам, которые были получены на основе построенных нами таблиц брачности для этносов разных когорт. Эти кумулятивные вероятности позволяют более полно представить брачные «траектории» исследуемых когорт. Они показаны на рисунках 3а-в для женщин и 4а-в для мужчин (графики построены для народов, у которых численность и мужчин, и женщин каждой исследуемой когорты в выборке микропереписи превышает 200 человек). Графики подтверждают, что как среди женщин, так и среди мужчин во всех трех когортах шансы остаться не вступившими в брак регулярно выше у осетин и карачаевцев. Уменьшение (но не полное исчезновение) этих различий наблюдается после 30 лет (у когорт, достигших этого возраста на момент микропереписи). Кумулятивные вероятности остаться незамужней/неженатым к разным возрастам для исследуемых когорт отражены также в таблицах П11-16 Приложения.

Обратимся теперь к данным ВПН-2010. На рисунке 5 показаны доли состоящих или состоявших в браке среди женщин, ответивших на вопрос о своем брачном статусе, по возрастам, а на рисунке 6 - аналогичное распределение среди мужчин. Легко видеть, что контрасты, наблюдавшиеся у когорт 1939-68 г.р., в целом сохранены и здесь. В Дагестане снова наблюдаются опережающие темпы брачности у табасаранцев и «отставание» по брачности у лакцев. Среди народов других рассматриваемых регионов осетины, карачаевцы и балкарцы вновь «отстают» от кабардинцев, черкесов и абазин. Также у мужчин сохраняется контраст между всеми дагестанскими и всеми недагестанскими народами: у первых, за исключением лакцев, доля состоящих или состоявших в браке заметно выше, чем у вторых, во всех возрастах. Из межэтнических различий, наблюдаемых по данным МП-94, к ВПН-2010 исчезло только «отставание» кумыков по накопленной брачности в ранних возрастах. Доли вступивших в первый брак среди мужчин и женщин исследуемых этносов разных возрастов по данным ВПН-2010 показаны также в таблицах П7-8 Приложения. 


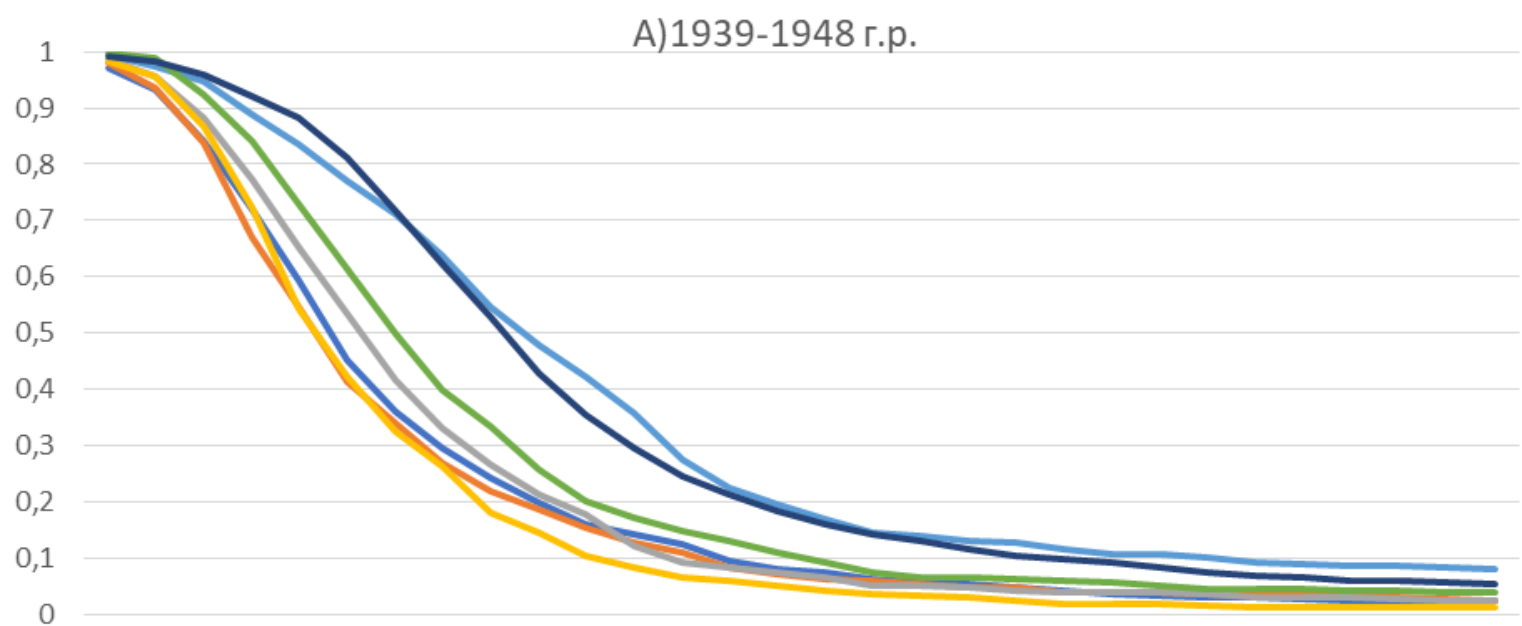

$16171819202122 \quad 23242526272829303132 \quad 33 \quad 3435 \quad 3637 \quad 383940 \quad 414243 \quad 44 \quad 45$

Б) $1949-1958$ г.p.
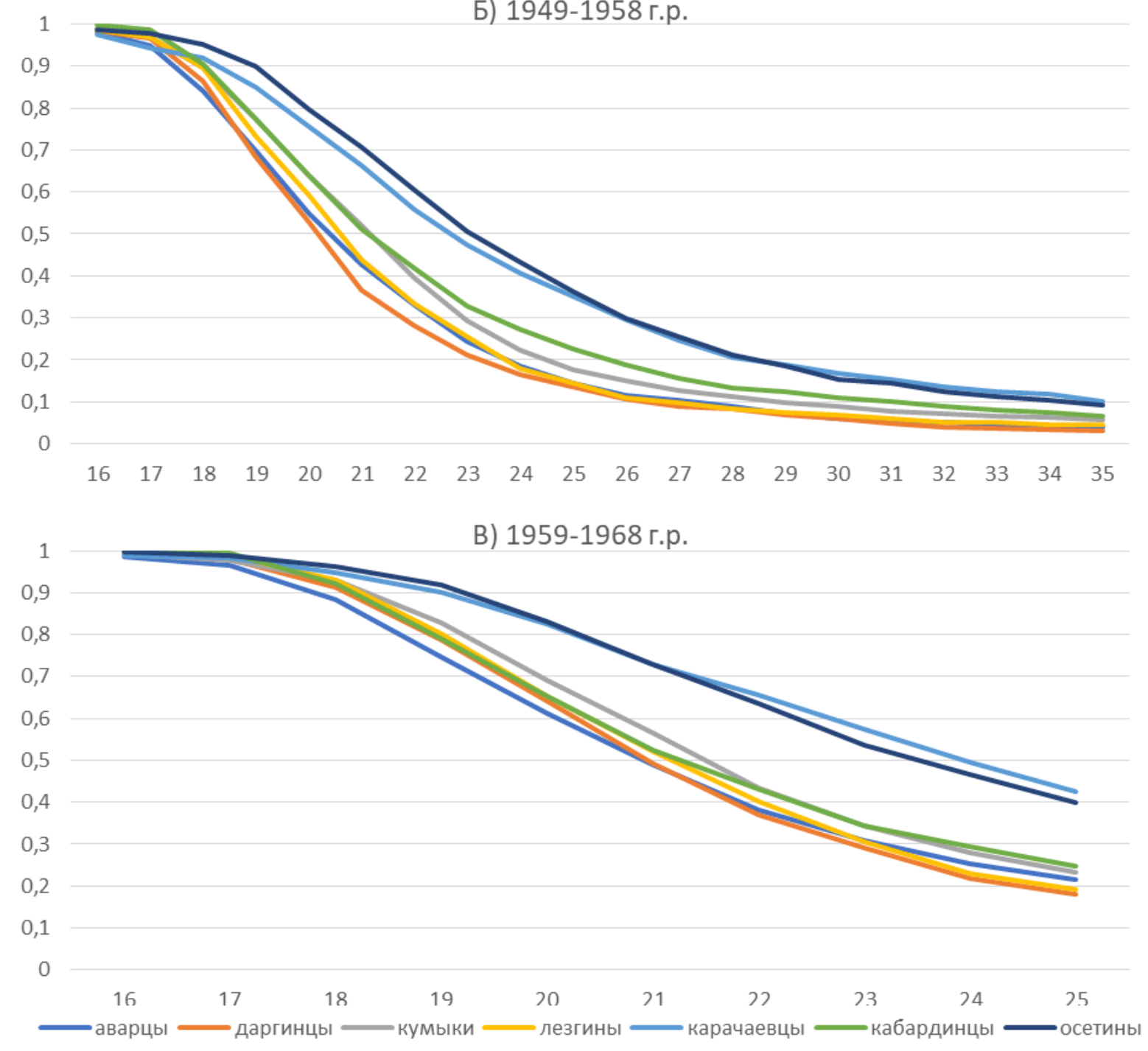

Рисунок 3. Кумулятивные вероятности не вступить в первый брак у женских когорт 1939-1968 г.p. по отдельным этносам Северного Кавказа

Источник: Рассчитано авторами по данным МП-94. 


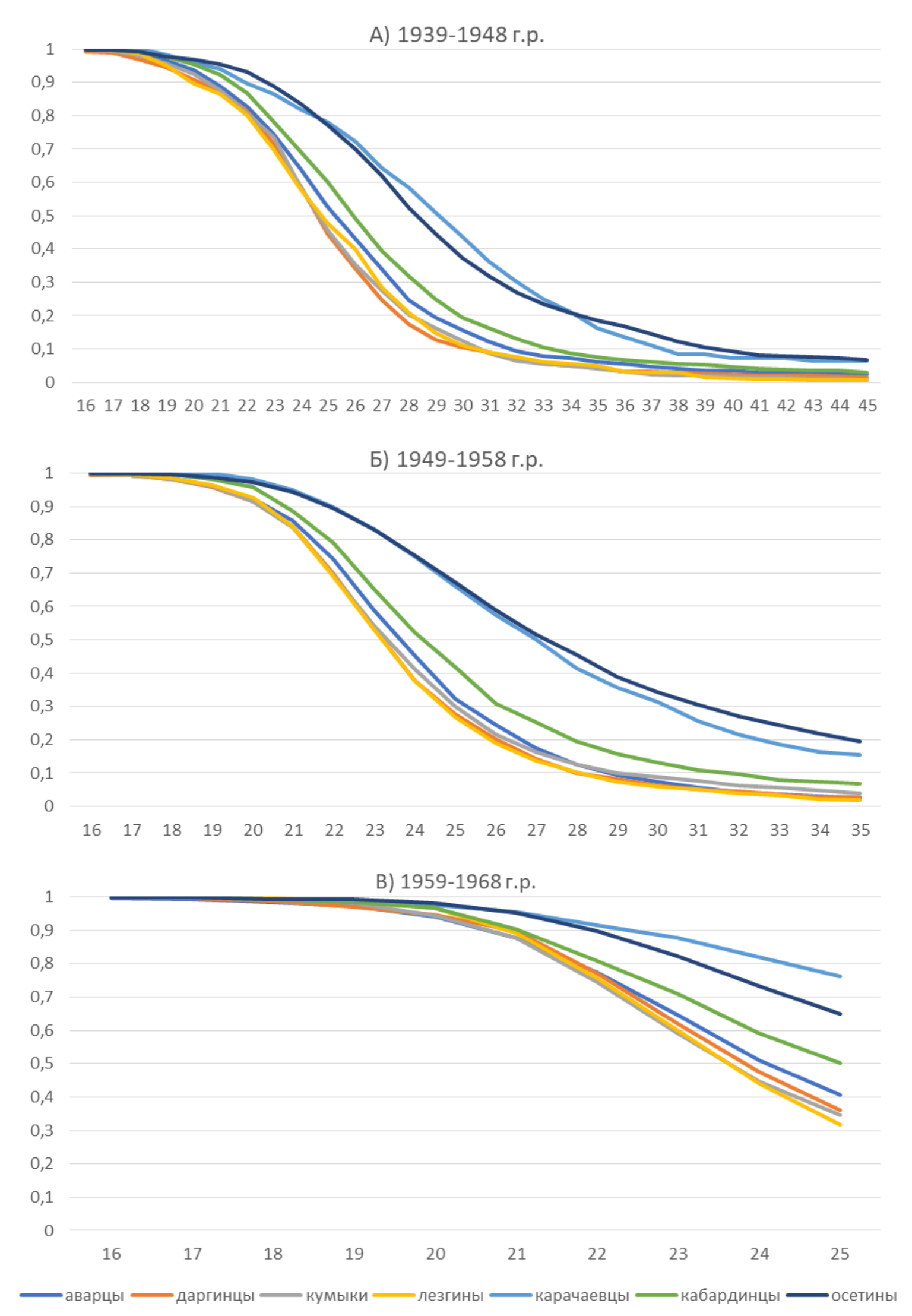

Рисунок 4. Кумулятивные вероятности не вступить в первый брак у мужских когорт 1939-1968 г.р. по отдельным этносам Северного Кавказа

Источник: Рассчитано авторами по даннымм МП-94. 


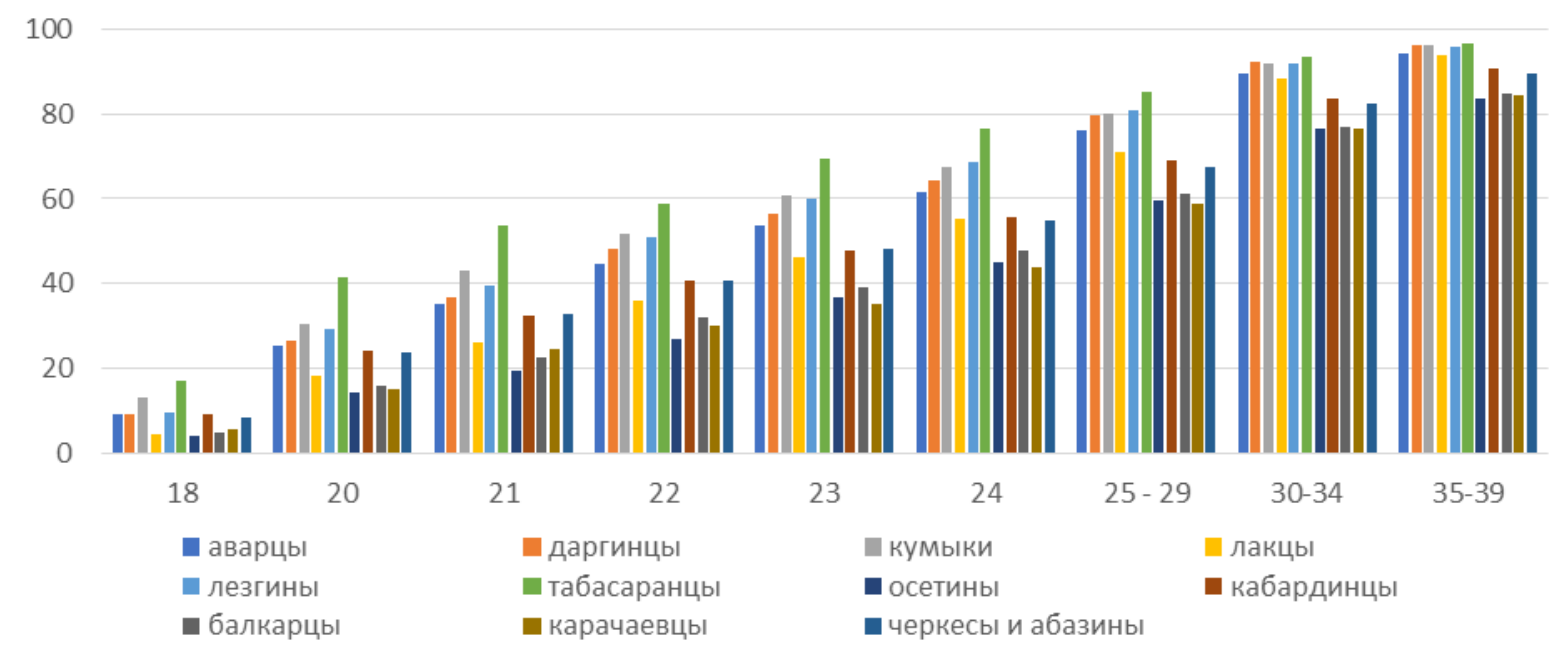

Рисунок 5. Доли вступивших в первый брак среди женщин отдельных этносов Северного Кавказа по возрастам, \%

Источник: Рассчитано авторами по данным ВПН-2010.

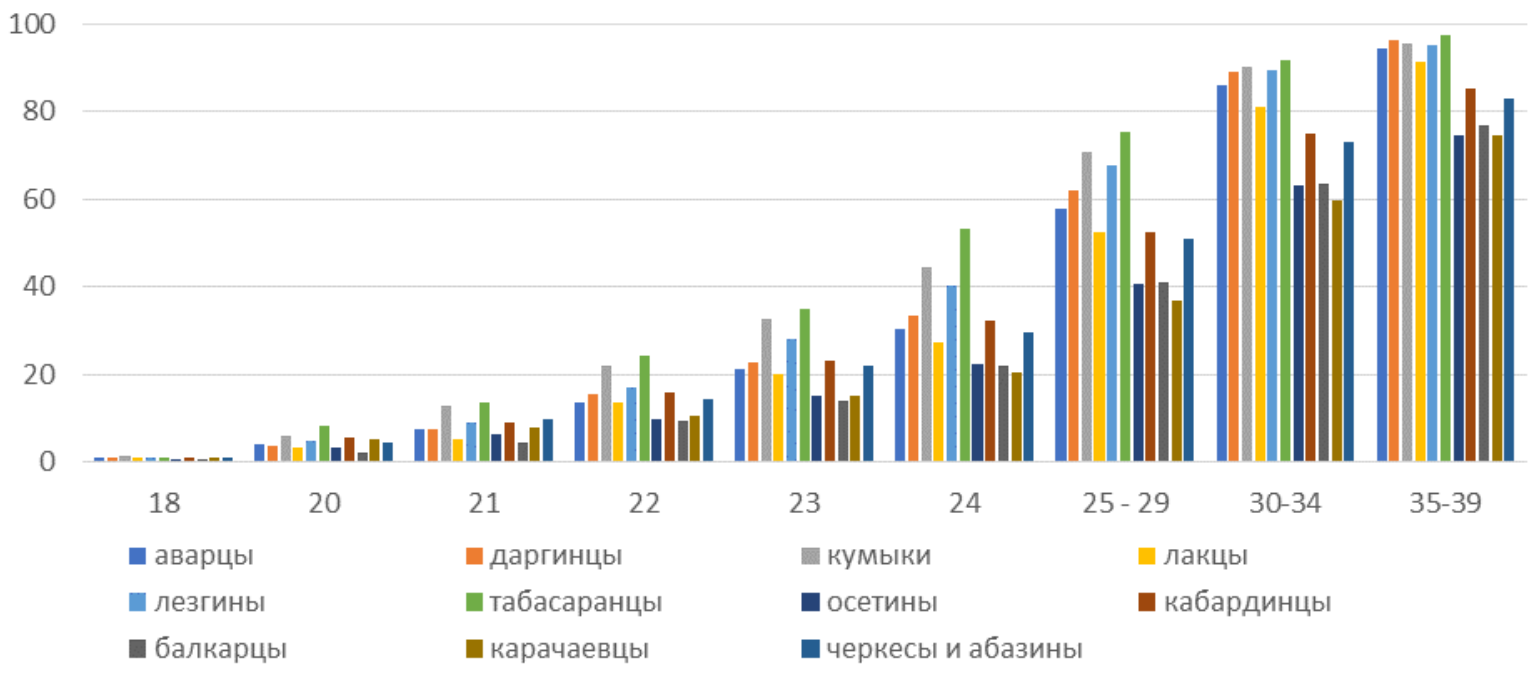

Рисунок 6. Доли вступивших в первый брак среди мужчин отдельных этносов Северного Кавказа по возрастам, \%

Источник: Рассчитано авторами по данным ВПН-2010.

Чтобы определить, сохранялись ли эти межэтнические контрасты на фоне меняющихся или стабильных возрастных характеристик брачности, сопоставим расчетные возраста вступления в брак (SMAM) изучаемых этносов по микропереписи и по ВПН-2010 (рисунки 7-8). Почти у всех народов SMAM на момент второго опроса был выше, чем на момент первого, как для женщин, так и для мужчин. То есть, судя по этим данным, сохранение межэтнических контрастов по возрастному распределению брачности имело место на фоне общего сдвига брачности к более старшим возрастам. Значения расчетных возрастов вступления в брак для исследуемых этносов по данным ВПН-2010 показаны также в таблицах П9-10 Приложения. 


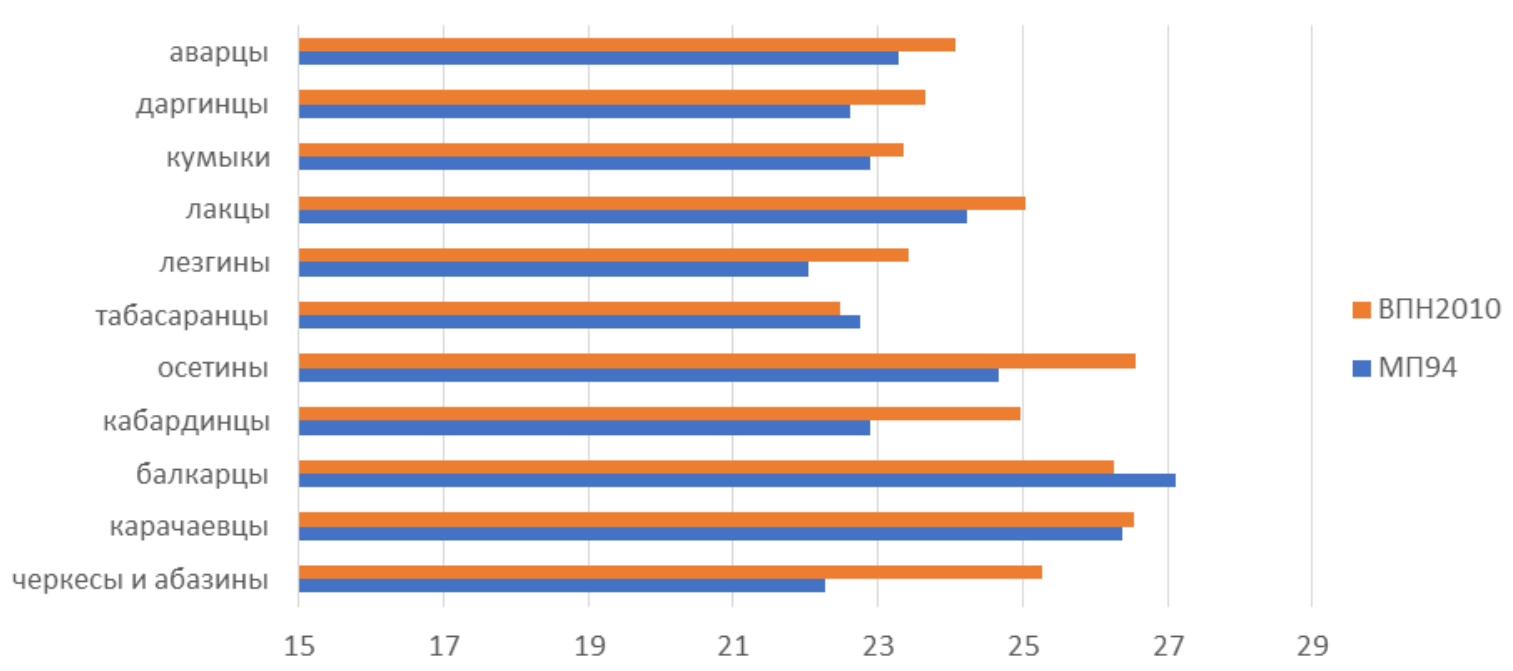

\section{Рисунок 7. Расчетные возраста вступления в брак (SMAM) для женщин отдельных этносов Северного Кавказа, лет}

Источник: Рассчитано авторами по данным МП-94 и ВПН-2010.

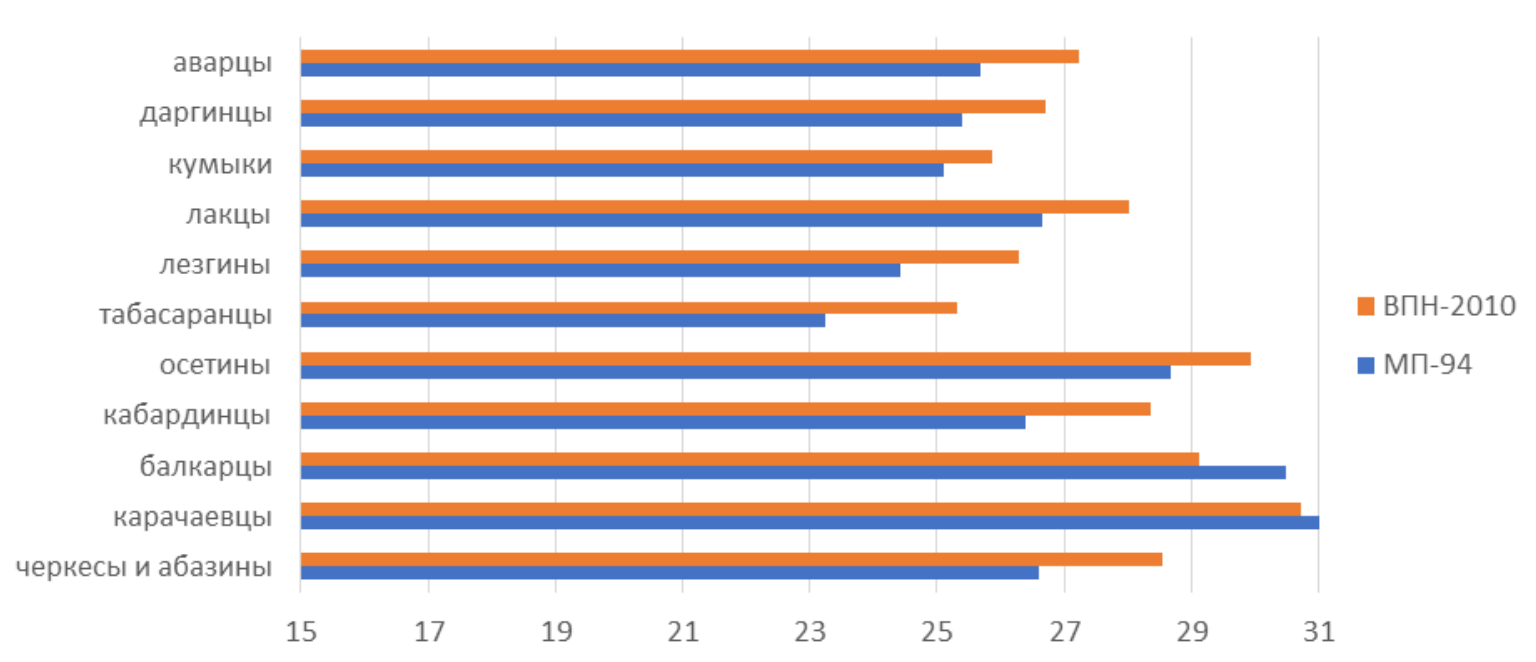

\section{Рисунок 8. Расчетные возраста вступления в брак (SMAM) для мужчин отдельных этносов Северного Кавказа, лет}

Источник: Рассчитано авторами по данным МП-94 и ВПН-2010.

Итак, анализ доступных нам статистических данных позволяет сделать следующие выводы. Во-первых, межэтнические контрасты по возрастным характеристикам брачности, наблюдавшиеся между северокавказскими народами в когортах 1939-68 г.р., сохранились и в период, когда в репродуктивном возрасте были более молодые когорты. Эти контрасты воспроизводятся в возрастном распределении вступивших и не вступивших в первый брак на момент ВПН-2010, включая возрастные группы моложе 30 лет на момент переписи. У мужчин и женщин состав этносов, отличающихся более ранней и более поздней брачностью, одинаков и межэтнические контрасты проявляются примерно с одинаковой силой. Во-вторых, эти межэтнические контрасты сохраняются на фоне общего «сдвига» 
брачности к более поздним возрастам в 1990-2010-е годы, который также был характерен и для женщин, и для мужчин.

\section{ОБСУЖДЕНИЕ РЕЗУЛЬТАТОВ}

Выводы из сопоставления данных МП-94 и ВПН-2010 влекут за собой как минимум два вопроса. Во-первых, какова причина межэтнических контрастов, которые были нами обнаружены у когорт 1939-1968 г.р.? Во-вторых, чем может объясняться стабильность этих контрастов на фоне социальных и демографических изменений, происходивших на Северном Кавказе в постсоветское время, в контексте которых ослабление межэтнических различий по рождаемости является ожидаемым сценарием?

Ответов на эти вопросы, способных претендовать на полноту, мы на сегодня не имеем. Исходя из имеющихся исследований по новейшей истории Северного Кавказа и накопленных у нас полевых данных, мы можем привести лишь несколько соображений, которые, как нам представляется, способны помочь в поиске ответов.

Относительно возможных причин межэтнических различий по брачности у «старших» когорт в нашем анализе мы ограничимся Дагестаном, где мы видели систематически более раннюю брачность у одного народа (табасаранцы) и систематически более позднюю - у другого (лакцы). Говоря о возможных причинах особенностей матримониального поведения этих народов, легко убедиться в том, что факторы, под действием которых могли сформироваться и сохраняться эти особенности, лежат и в социально-экономической, и культурной плоскостях.

Так, табасаранцы, народ, чья историческая родина находится в горах южного Дагестана, во второй половине XX века отличались от других дагестанских этносов не только более ранней брачностью, но и более высокой рождаемостью (Казенин, Козлов 2016). Насколько можно судить по результатам полевых интервью с представителями старшего поколения табасаранцев, проведенным в Табасаранском и Хивском районах в 2016 г., высокая рождаемость у этого народа часто была результатом сознательного решения иметь больше детей, поскольку дети были необходимы в качестве рабочих рук: среди сельских табасаранцев вплоть до 1990-х годов большое распространение имело ковроткачество, которым занимались в том числе в частных домах, активно привлекая детей к этому труду. То есть стимулом высокой рождаемости была экономическая выгода от многодетности, по-видимому, исчезнувшая у табасаранцев позже, чем у других дагестанских народов. О причинах ранней брачности в наших интервью 2016 г. речи, к сожалению, не шло. Можно предположить два механизма взаимосвязи повышенной рождаемости и ранней брачности. С одной стороны, сознательная установка на многодетность могла стимулировать раннее создание семей для продления периода репродуктивной активности. С другой стороны, большая рождаемость могла быть причиной более ранней брачности следующего поколения. В условиях, когда проживание детей отдельно от родителей до вступления в брак не одобрялось традициями, наличие в семье большого числа взрослых детей могло заставлять родителей раньше организовывать 
их вступление в брак, особенно после достижения их младшими братьями и сестрами подросткового возраста, позволявшего участвовать в домашнем труде.

Однако все эти факторы вряд ли могли поддерживать более раннюю брачность среди тех поколений табасаранцев, которые были в репродуктивном возрасте на момент ВПН-2010. Более того, влияние этих факторов на возрастное распределение брачности, скорее всего, существенно ослабло и ранее, еще в последние советские десятилетия. Дело в том, что во второй половине 1960 -х - начале 1970-х годов имело место интенсивное организованное переселение табасаранцев на равнину, начавшееся после разрушительного землетрясения в горах южного Дагестана весной 1966 г. (Османов 2000: 250-309). В результате, если по данным Всесоюзной переписи населения 1959 г. в равнинной части Дагестана проживало всего 6,8\% от табасаранского населения региона, то по данным Всесоюзной переписи населения 1970 г. - уже 12\%. В 1970-1980-е годы переселение с гор в города и районы, куда первоначально были организованно перемещены табасаранцы из наиболее пострадавших от землетрясения сел, продолжалось, в результате чего, например, в городе Дагестанские Огни доля табасаранцев выросла с 11,4\% в 1970 г. до 31,3\% в 1989 г. (Казенин 2019b). Очевидно, что интенсивное переселение на равнину вело к ломке того хозяйственного уклада, который, как мы предположили выше, служил поддерживающим фактором для ранней брачности.

Что касается лакцев, то их относительно поздняя брачность на сегодняшний день воспринимается самими представителями этого народа прежде всего как дань традиции. Так, по крайней мере, характеризовали ее респонденты в ходе полевого исследования, проведенного нами в Лакском районе Дагестана в 2015 г. В ходе интервью звучали мнения, что среди лакцев считается традиционно необходимым, чтобы мужчина до брака подтвердил свою экономическую независимость от старших родственников, построил дом и так далее. Возможно, такие нормы сложились еще в XIX веке, когда среди лакцев выше, чем среди других народов Дагестана, была доля ремесленников-отходников, работавших за пределами Дагестана (Карпов, Капустина 2011). Такая форма трудовой деятельности обычно требовала от молодых людей достаточно долгих лет ученичества, только после которых они могли начать собственное дело и считались «готовыми» к браку по традиционным меркам. Однако ко второй половине XX века эти реалии давно ушли в прошлое, Лакия прошла через те же социальные преобразования, что и весь Дагестан в первые десятилетия советской власти. Нельзя исключать при этом, что в советское время более позднюю по сравнению с другими дагестанскими народами брачность среди лакцев поддерживали другие обстоятельства, не связанные с традициями: этот народ раньше других народов Дагестана начал интенсивную миграцию в города, что подтверждается высокой долей городского населения среди лакцев по переписям 1970 и 1979 г. (доля сельских жителей среди лакцев, по данным этих переписей, составила соответственно 42 и 46\%, что было значительно меньше, чем у крупнейших народов Дагестана: у аварцев эта доля составляла соответственно 81 и 75\%, у даргинцев - 78 и 74\%).

Приведенные примеры показывают возможное разнообразие факторов, влияющих на возрастную модель брачности у того или иного этноса. Подчеркнем, что даже для двух рассмотренных этносов предложенные объяснения носят предварительный характер и, 
скорее всего, потребуют уточнений по результатам полевых и более глубоких историкокультурных исследований.

Обратимся теперь к вопросу о возможных причинах стабильности межэтнических различий по брачности. Как мы видели выше, одно из стандартных в демографических исследованиях предположений говорит о том, что межэтнические различия по брачнорепродуктивному поведению более стабильны при высоком уровне «сегрегации» в расселении этносов. Северный Кавказ по характеристикам расселения этносов весьма неоднороден (подробно см. (Белозеров 2005; Карпов, Капустина 2011)). Модель расселения, при которой каждый народ жил в основном на «своей» территории, уверенно ушла в прошлое еще в середине XX века, однако говорить о полном стирании межэтнических границ внутри многонациональных регионов, включенных в наше исследование, на сегодня явно преждевременно. Например, для Дагестана по-прежнему характерны моноэтничные села в горах, а в равнинных селах, как правило, от одного до трех этносов составляют более 90\% всего населения. Интересно, что для табасаранцев, сохранивших, как мы видели выше, значимо более раннюю возрастную модель брачности, интенсивное переселение на равнину в малой степени нарушило компактное совместное проживание представителей этого народа: на 2010 г. более 50\% равнинных табасаранцев было сосредоточено в тех же городах и районах, куда началось переселение этого народа с гор после 1966 г. Вместе с тем в столице региона Махачкале и образующим с ней единую агломерацию городе Каспийск, в которых фактически проживает на сегодня, по имеющимся оценкам, не менее трети населения всего Дагестана, уровень этнического смешения очень высок. В Карачаево-Черкесии, Кабардино-Балкарии и Северной Осетии для городов в целом характерно смешанное проживание всех основных этносов (хотя среди малых городов есть исключения), однако имеются крупные села и целые сельское районы, в которых состав населения практически мононационален. Для того, чтобы оценить, насколько влияет характер расселения этносов на сохранность их традиционных возрастных моделей брачности, необходимы дополнительные количественные полевые исследования, которые позволили бы изучить связь между характеристиками матримониального поведения индивида и долей представителей его родного этноса в населенном пункте, где он проживает или проживал ранее, среди лиц, с которыми он регулярно контактирует, и др.

Однако само по себе ослабление этнических границ в расселении, в ежедневных контактах и др. не обязательно влечет за собой ослабление этнического многообразия в матримониальном поведении. Предварительные оценки говорят о том, что ослабление этнической сегрегации в расселении на Северном Кавказе само может происходить без «интернационализации» сферы брака. Наши полевые исследования, проведенные качественными методами в крупнейших городах Северного Кавказа, включая полиэтничную Махачкалу, показывают, что точка зрения, согласно которой брак с человеком другой национальности нежелателен, по крайней мере, не является для населения этих городов экзотической (см. также: (Шахбанова 2008)). Это подтверждается и данными ВПН-2010 о доле смешанных семей среди народов Северного Кавказа (Сороко 2018: 179): даже у наиболее крупных народов Северного Кавказа доля смешанных браков составляет менее 10\%, что вряд ли можно считать высоким уровнем для этносов, 
проживающих в регионах со сложным национальным составом. Интересно при этом, что доля мужчин, состоявших в смешанном браке, из всех мужчин, состоявших в браке на момент ВПН-2010, у большинства этносов была в 1,5-2 раза выше, чем соответствующая доля женщин, что согласуется с предположением о большей зависимости демографического поведения женщин он традиционных семейных норм. К сожалению, данные опросов и официальной статистики на текущий момент не позволяют оценить, насколько эти тенденции присутствуют в поколениях северокавказцев, вступивших во взрослую жизнь в последнее десятилетие.

Что касается возможных теоретических выводов из проведенного сопоставления данных МП-94 и ВПН-2010, то имеет смысл, на наш взгляд, остановиться на двух из них.

Первый вывод касается типологии моделей организации семьи. Со времен работы Дж. Хайнала (Hajnal 1982) стандартным является представление о наличии двух исторических типов семейной организации. Для одного типа характерен молодой возраст вступления в брак и проживание молодых семей в одном домохозяйстве с родителями одного из супругов, для другого - сравнительно поздний возраст вступления в брак и проживание семей отдельно от родителей супругов. Адекватность такого жесткого бинарного противопоставления в последующих исследованиях была поставлена под вопрос (см., например, (Szołtysek 2008)). Впоследствии были предложены более сложные подходы к типологии организации семьи, при этом защищалась гипотеза, что каждому типу организации семьи универсально соответствуют достаточно жесткие возрастные рамки, в которых ожидается вступление в первый брак (они, разумеется, могут быть разными для мужчин и женщин). Примером такого подхода может быть исследование С. Кармишель (Carmichael 2011). Однако данные по Северному Кавказу заставляют допустить, что в действительности связь между принципами организации семьи и возрастом вступления в брак может быть вариативной. Чтобы убедиться в этом, достаточно посмотреть на пример Карачаево-Черкесии, где, напомним, обнаружен заметный контраст по возрасту вступления в брак между карачаевцами, с одной стороны, и черкесами и абазинами, с другой. Как показывают наши полевые исследования, у всех этих народов сельский семейный уклад, осознаваемый их представителями в качестве «правил предков», с точки зрения типологии семьи, предложенной С. Кармишель, примерно одинаков. Его характеризуют активное участие старших родственников в организации брака; проживание молодой семьи либо в доме родителей мужа, либо, по крайней мере, в том же селе, что и родители мужа (при проживании родителей супругов в разных селах не считалось нормой проживание молодых в селе, где живут родители невесты); запрет на близкородственные браки. Как мы видим, эти «типологические» сходства семейной организации не ведут к единообразию по возрасту вступления в брак. Связь между типом организации семьи и возрастом вступления в брак, видимо, может быть осложнена другими факторами, которые еще предстоит установить.

Второй вывод состоит в том, что сам по себе процесс повышения возраста вступления в брак не всегда оказывается синхронизирован с ослаблением межэтнических различий по брачности. Такой вывод представляет интерес в том отношении, что оба указанных процесса стандартно рассматриваются как элементы «детрадиционализации» брачно-репродуктивного поведения. Пример Северного Кавказа подтверждает, что разные 
элементы этой «детрадиционализации» могут происходить не синхронно, и показывает необходимость исследования разных вариантов их взаимораспределения во времени.

\section{БЛАГОДАРНОСТИ}

Большую помощь в работе над статьей оказали Д.Д. Богоявленский, С.В. Захаров и В.А. Козлов, которые, разумеется, не несут ответственности за возможные недостатки окончательного варианта статьи.

\section{ЛИТЕРАТУРА}

Андреев Е.М. (2012). О точности результатов Российских переписей населения и степени доверия к разным источникам информации о населении. Вопросы статистики, 11, 2135 .

Белозеров В.С. (2005). Этническая карта Северного Кавказа. Москва: О.Г.И.

Богоявленский Д.Д. (2012). Перепись 2010: этнический срез. Демоскоn Weekly, 531 532. http://demoscope.ru/weekly/2012/0531/index.php

Дарский Л.Е., Ильина И.П. (2000). Брачность в России: анализ таблии брачности. Москва: Информатика.

Захаров С.В. (2018). Брачная структура населения, заключение и прекращение браков в России в свете результатов микропереписи населения 2015 г. В С.В. Захаров (Ред.) Население России: двадиать четвертый ежегодный демографический доклад (с.99159). Москва: Изд. дом Высшей школы экономики.

Казенин К. И., Козлов В.А. (2016). Омоложение материнства в Дагестане: тенденция или артефакт? (Предварительные результаты обследования сельского населения). Демографическое обозрение, 3(3), 100-123. https://doi.org/10.17323/demreview.v3i3.1748

Казенин К.И., Козлов В.А. (2017). Особенности брачно-репродуктивного поведения населения в Республике Дагестан: их причины и социально-экономические последствия. Вестник Института экономики РАН, 2, 65-81.

Казенин К. И. (2019а). Традиционализм семейного уклада и возрастные характеристики брачности: о чем говорит пример Карачаево-Черкесии? Демографическое обозрение, 6(3), 98-127. https://doi.org/10.17323/demreview.v6i3.9857

Казенин К. И. (2019б). Миграция северокавказского населения с гор на равнину: вызовы разнообразия. Журнал исследований социальной политики, 17(1), 23-38. https://doi.org/10.17323/727-0634-2019-17-1-23-38

Карпов Ю.Ю. (2001). Женское пространство в культуре народов Кавказа. СПб.: Петербургское востоковедение.

Карпов Ю.Ю., Капустина Е.А. (2011). Горцы после гор. Миграционные процессы в Дагестане в XX - начале XXI века: их социальные и этнокультурные последствия и перспективы. СПб.: Петербургское востоковедение. 
Мкртчян Н.В. (2019). Миграция на Северном Кавказе сквозь призму несовершенной статистики. Журнал исследований соџиальной политики, 17(1), 7-22. https://doi.org/10.17323/727-0634-2019-17-1-7-22

Османов А.И. (2000). Аграрные преобразования в Дагестане и переселение гориев на равнину (20-70-е годы 20в.). Махачкала.

Пьянкова А.И., Щербакова Е.М., Васин, С.А. (2018). Микропереписи населения России: прошлое, настоящее и будущее. Демографическое обозрение, 5(2), 61-102. https://doi.org/10.17323/demreview.v5i2.7935

Стародубровская И.В. (2019). Кризис традиционной северокавказской семьи в постсоветский период и его социальные последствия. Журнал исследований сочииальной политики, 17(1), 39-56. DOI: https://doi.org/10.17323/727-0634-2019-17-1-3956

Сороко Е.Л. (2018). Этнический состав населения и межэтнические браки в России по данным переписей населения. В С.В. Захаров (Ред.) Население России: двадиать четвертый ежегодный демографический доклад. М.: Изд. дом Высшей школы экономики.

Тайсаев Д. М. (2015). Этногенез народов Кавказа. Нальчик: Издательство М. и В. Котляровых.

Шахбанова М.М. (2008). Отношение к межнациональным бракам в этническом сознании дагестанцев. Социологические исследования, 11, 72-76.

Эдиев Д.М. (2003). Демографические потери депортированных народов СССР . Ставрополь.

Carmichael S. (2011). Marriage and power: Age at first marriage and spousal age gap in lesser developed countries. The History of the Family, 16(4), 416-436. https://doi.org/10.1016/j.hisfam.2011.08.002

Crul M., Schneider J., Lelie F. (Eds.) (2012). The European second generation compared: does the integration context matter? Amsterdam: Amsterdam university press.

Gruber S., Szołtysek M. (2012). Quantifying Patriarchy: An Explorative Comparison of Two Joint Family Societies. MPIDR Working Paper WP 2012-017, April 2012.

Hajnal J. (1953). Age at Marriage and Proportions Marrying. Population Studies, 7, 111-132.

Hajnal J (1982). Two kinds of preindustrial household formation systems. Population and Development Review, 8(3), 449-494.

Lerch M. (2013). Patriarchy and fertility in Albania. Demographic Research, 29, 133-166. DOI: https://doi.org/10.4054/DemRes.2013.29.6

Mason K. O. (1987). The Impact of Women's Social Position on Fertility in Developing Countries. Sociological Forum, 2(4), 718-745.

Parrado E.A. (2011). How High is Hispanic/Mexican Fertility in the United States? Immigration and Tempo Considerations. Demography, 48(3), 1059-1080. https://doi.org/10.1007/s13524011-0045-0

Szołtysek M. (2008). Three kinds of preindustrial household formation system in historical Eastern Europe: A challenge to spatial patterns of the European family. The History of the Family, 13, 223-257. https://doi.org/10.1016/j.hisfam.2008.05.003 
United Nations (1990). Patterns of first marriage. Timing and prevalence. Department of International Economic and Social Affairs. ST/ESA/SER.R/111. New York.

Yavuz S. (2004). Completing the fertility transition: Third birth developments by language groups in Turkey. Demographic Research, 15, 435-460.

https://doi.org/10.4054/DemRes.2006.15.15 


\section{ПРИЛОЖЕНИЯ}

Таблица П1. Накопленная брачность у женщин 1939-48 г.р. по отдельным народам Северного Кавказа (доли вступивших в первый брак к разным возрастам), \%

\begin{tabular}{|c|c|c|c|c|c|c|c|c|c|c|}
\hline \multirow{2}{*}{ Народы } & \multicolumn{10}{|c|}{ Возраст, лет } \\
\hline & 18 & 20 & 21 & 22 & 23 & 24 & 25 & 30 & 35 & 40 \\
\hline аварцы & 16,0 & 40,6 & 54,8 & 64,0 & 70,4 & 75,6 & 80,2 & 91,8 & 95,1 & 96,9 \\
\hline даргинцы & 16,1 & 45,4 & 58,7 & 66,0 & 73,1 & 78,1 & 81,3 & 92,9 & 95,3 & 96,6 \\
\hline кумыки & 11,7 & 34,8 & 46,5 & 58,2 & 66,7 & 73,3 & 78,7 & 92,5 & 95,7 & 96,8 \\
\hline лакцы & 6,5 & 27,4 & 38,7 & 51,6 & 62,9 & 70,4 & 76,9 & 93,0 & 96,8 & 97,8 \\
\hline лезгины & 13,4 & 45,7 & 57,8 & 67,4 & 73,8 & 81,8 & 85,3 & 94,9 & 97,6 & 98,7 \\
\hline табасаранцы & 19,7 & 59,0 & 66,4 & 74,6 & 83,6 & 87,7 & 91,0 & 95,9 & 98,4 & 98,4 \\
\hline осетины & 4,1 & 11,7 & 18,9 & 28,4 & 37,8 & 47,1 & 57,1 & 81,7 & 89,4 & 93,2 \\
\hline кабардинцы & 7,7 & 27,0 & 38,5 & 50,1 & 60,0 & 66,6 & 74,3 & 89,1 & 93,7 & 95,5 \\
\hline балкарцы & 3,2 & 18,3 & 27,0 & 34,9 & 44,4 & 57,9 & 64,3 & 84,9 & 92,9 & 96,0 \\
\hline карачаевцы & 5,4 & 16,4 & 23,1 & 28,8 & 36,1 & 45,5 & 52,2 & 80,3 & 87,3 & 90,6 \\
\hline черкесы и абазины & 14,2 & 32,7 & 43,8 & 53,1 & 61,1 & 66,0 & 71,0 & 93,2 & 95,1 & 97,5 \\
\hline
\end{tabular}

Источник: Рассчитано авторами по данным МП-94.

Таблица П2. Накопленная брачность у мужчин 1939-48 г.р. по отдельным народам Северного Кавказа (доли вступивших в первый брак к разным возрастам), \%

\begin{tabular}{l|r|r|r|r|r|c|c|c|c|c}
\hline \multirow{2}{*}{ Народы } & \multicolumn{10}{c}{ Возраст, лет } \\
\cline { 2 - 11 } & 18 & 20 & 21 & \multicolumn{1}{c}{22} & 23 & 24 & 25 & 30 & 35 & 40 \\
\hline аварцы & 1,4 & 6,3 & 11,2 & 17,4 & 25,7 & 36,2 & 47,4 & 84,3 & 93,9 & 96,6 \\
даргинцы & 3,0 & 9,1 & 12,8 & 18,6 & 28,6 & 41,4 & 55,3 & 89,5 & 95,6 & 97,7 \\
кумыки & 1,9 & 7,4 & 12,5 & 19,4 & 26,6 & 41,7 & 54,4 & 87,5 & 95,8 & 98,1 \\
лакцы & 0,8 & 2,3 & 3,9 & 7,8 & 10,1 & 13,2 & 23,3 & 78,3 & 89,9 & 94,6 \\
лезгины & 1,5 & 10,2 & 13,4 & 19,8 & 30,3 & 42,3 & 52,2 & 88,9 & 95,0 & 98,8 \\
табасаранцы & 4,0 & 9,3 & 14,6 & 25,8 & 41,1 & 54,3 & 62,9 & 86,1 & 90,7 & 94,0 \\
осетины & 0,8 & 3,1 & 4,5 & 6,8 & 11,1 & 16,3 & 22,7 & 62,6 & 81,3 & 90,8 \\
кабардинцы & 0,9 & 4,6 & 7,9 & 13,1 & 22,0 & 30,9 & 39,9 & 80,6 & 92,5 & 95,3 \\
балкарцы & 0,8 & 4,6 & 5,4 & 7,7 & 12,3 & 21,5 & 27,7 & 72,3 & 89,2 & 93,8 \\
карачаевцы & 0,0 & 4,0 & 6,0 & 10,3 & 13,5 & 18,3 & 21,8 & 56,3 & 83,7 & 92,9 \\
черкесы и абазины & 0,7 & 5,0 & 6,4 & 10,0 & 17,9 & 29,3 & 38,6 & 78,6 & 89,3 & 92,9 \\
\hline
\end{tabular}

Источник: Рассчитано авторами по данным МП-94.

ТаблицаП3. Накопленная брачность у женщин 1949-58 г.р. по отдельным народам

Северного Кавказа (доли вступивших в первый брак к разным возрастам), \%

\begin{tabular}{l|r|r|r|r|r|r|r|r|r}
\hline \multirow{2}{*}{ Народы } & \multicolumn{10}{|c}{ Возраст, лет } \\
\cline { 2 - 10 } & 18 & 20 & 21 & 22 & 23 & 24 & 25 & 30 & 35 \\
\hline аварцы & 15,8 & 44,9 & 57,2 & 66,9 & 75,8 & 81,6 & 85,6 & 94,0 & 96,0 \\
даргинцы & 13,6 & 47,1 & 63,5 & 71,8 & 78,8 & 83,5 & 86,4 & 94,1 & 96,9 \\
кумыки & 10,3 & 35,9 & 47,9 & 60,3 & 70,6 & 77,7 & 82,3 & 91,2 & 94,4 \\
лакцы & 5,8 & 24,3 & 40,6 & 49,3 & 60,5 & 68,1 & 73,9 & 88,4 & 93,5 \\
лезгины & 10,5 & 40,6 & 56,2 & 66,7 & 74,6 & 82,1 & 85,6 & 93,1 & 95,5 \\
табасаранцы & 13,1 & 54,9 & 69,0 & 79,8 & 84,2 & 86,2 & 87,9 & 92,3 & 94,3 \\
осетины & 4,8 & 20,2 & 29,3 & 39,4 & 49,4 & 56,8 & 63,8 & 84,5 & 90,8 \\
кабардинцы & 9,6 & 35,9 & 48,7 & 58,2 & 67,3 & 72,7 & 77,3 & 88,9 & 93,4 \\
балкарцы & 4,3 & 21,5 & 35,4 & 41,1 & 50,0 & 56,6 & 63,6 & 77,5 & 84,1 \\
карачаевцы & 8,0 & 24,5 & 33,8 & 44,1 & 52,5 & 59,2 & 65,0 & 83,1 & 90,1 \\
черкесы и абазины & 8,1 & 37,4 & 49,4 & 59,1 & 69,8 & 76,2 & 79,6 & 89,8 & 94,5 \\
\hline
\end{tabular}

Источник: Рассчитано авторами по данным МП-94. 
Таблица П4. Накопленная брачность у мужчин 1949-58 г.р. по отдельным народам Северного Кавказа (доли вступивших в первый брак к разным возрастам), \%

\begin{tabular}{l|c|c|r|c|c|c|c|c|c}
\hline \multirow{2}{*}{ Народы } & \multicolumn{10}{|c}{ Возраст, лет } \\
\cline { 2 - 10 } & 18 & \multicolumn{1}{c}{20} & \multicolumn{1}{c}{21} & 22 & 23 & 24 & 25 & 30 & 35 \\
\hline аварцы & 1,6 & 7,7 & 14,2 & 25,8 & 41,1 & 54,9 & 67,7 & 92,7 & 97,5 \\
даргинцы & 1,8 & 8,6 & 16,1 & 30,2 & 46,7 & 62,2 & 72,3 & 93,9 & 97,3 \\
кумыки & 1,8 & 8,6 & 16,2 & 30,6 & 45,6 & 58,8 & 69,9 & 91,0 & 96,0 \\
лакцы & 0,0 & 2,2 & 4,4 & 11,1 & 23,0 & 34,1 & 43,3 & 83,3 & 91,9 \\
лезгины & 1,4 & 7,2 & 15,9 & 31,1 & 47,0 & 62,1 & 73,2 & 94,2 & 98,2 \\
табасаранцы & 3,3 & 15,3 & 25,2 & 47,5 & 66,5 & 76,0 & 81,4 & 93,8 & 96,7 \\
осетины & 0,5 & 2,7 & 5,6 & 10,6 & 17,0 & 24,6 & 32,8 & 65,7 & 80,5 \\
кабардинцы & 0,4 & 4,3 & 11,3 & 21,0 & 34,7 & 47,7 & 58,1 & 87,0 & 93,3 \\
балкарцы & 0,8 & 3,2 & 4,0 & 10,7 & 16,3 & 25,8 & 33,7 & 71,0 & 86,9 \\
карачаевцы & 0,0 & 1,9 & 5,2 & 10,1 & 16,9 & 24,9 & 34,0 & 68,7 & 84,5 \\
черкесы и абазины & 1,6 & 2,4 & 6,1 & 18,0 & 29,4 & 42,4 & 56,7 & 83,3 & 92,2 \\
\hline
\end{tabular}

Источник: Рассчитано авторами по данным МП-94.

Таблица П5. Накопленная брачность у женщин 1959-68 г.p. по отдельным народам

Северного Кавказа (доли вступивших в первый брак к разным возрастам), \%

\begin{tabular}{l|r|r|r|r|r|r|r}
\hline \multirow{2}{*}{ Народы } & \multicolumn{7}{c}{ Возраст, лет } \\
\cline { 2 - 8 } & 18 & 20 & 21 & 22 & 23 & 24 & 25 \\
\hline аварцы & 11,6 & 38,9 & 51,1 & 61,8 & 69,0 & 74,7 & 78,6 \\
даргинцы & 8,8 & 35,9 & 50,8 & 63,0 & 70,9 & 78,2 & 82,0 \\
кумыки & 7,0 & 30,8 & 43,5 & 56,5 & 65,5 & 72,2 & 76,6 \\
лакцы & 4,9 & 23,0 & 34,1 & 47,0 & 56,6 & 65,4 & 71,1 \\
лезгины & 7,0 & 34,6 & 47,9 & 59,8 & 69,3 & 77,0 & 80,8 \\
табасаранцы & 6,5 & 29,6 & 42,2 & 53,3 & 61,9 & 68,4 & 72,8 \\
осетины & 3,8 & 17,0 & 27,1 & 36,5 & 46,2 & 53,5 & 60,1 \\
кабардинцы & 8,0 & 34,6 & 47,4 & 56,9 & 65,5 & 70,5 & 75,4 \\
балкарцы & 3,6 & 11,4 & 16,7 & 27,0 & 33,8 & 41,3 & 52,0 \\
карачаевцы & 5,4 & 17,6 & 27,0 & 34,4 & 42,6 & 50,5 & 57,4 \\
черкесы и абазины & 8,6 & 38,7 & 52,0 & 62,8 & 71,0 & 76,2 & 80,3 \\
\hline
\end{tabular}

Источник: Рассчитано авторами по данным МП-94.

Таблица Пб. Накопленная брачность у мужчин 1959-68 г.р. по отдельным народам Северного Кавказа (доли вступивших в первый брак к разным возрастам), \%

\begin{tabular}{l|r|r|r|r|r|c|c}
\hline \multirow{2}{*}{ Народы } & \multicolumn{7}{c}{ Возраст, лет } \\
\cline { 2 - 8 } & 18 & 20 & 21 & 22 & 23 & 24 & 25 \\
\hline аварцы & 1,5 & 5,8 & 12,2 & 22,5 & 35,4 & 48,9 & 59,3 \\
даргинцы & 1,2 & 5,2 & 10,1 & 23,1 & 38,0 & 52,2 & 63,9 \\
кумыки & 0,4 & 5,5 & 12,4 & 25,4 & 40,9 & 55,2 & 65,4 \\
лакцы & 2,1 & 3,0 & 4,5 & 7,9 & 14,5 & 24,8 & 37,6 \\
лезгины & 0,5 & 3,4 & 10,8 & 24,4 & 39,9 & 55,7 & 68,2 \\
табасаранцы & 1,2 & 7,8 & 20,5 & 37,3 & 54,0 & 65,2 & 75,8 \\
осетины & 0,6 & 1,9 & 4,9 & 10,2 & 17,6 & 26,5 & 35,1 \\
кабардинцы & 0,6 & 3,2 & 9,6 & 19,1 & 29,0 & 40,8 & 49,9 \\
балкарцы & 0,0 & 0,6 & 3,3 & 7,4 & 12,2 & 18,4 & 25,5 \\
карачаевцы & 0,6 & 2,4 & 4,5 & 8,3 & 12,2 & 18,0 & 23,9 \\
черкесы и абазины & 1,0 & 1,6 & 6,1 & 12,9 & 23,9 & 35,0 & 41,1 \\
\hline
\end{tabular}

Источник: Рассчитано авторами по данньмм МП-94. 
Таблица П7. Доли вступивших в первый брак среди женщин отдельных этносов Северного Кавказа по возрастам, \%

\begin{tabular}{l|r|c|c|c|c|c|c|c|c}
\hline \multirow{2}{*}{ Народы } & \multicolumn{10}{c}{ Возраст, лет } \\
\cline { 2 - 10 } & \multicolumn{1}{|c|}{18} & 20 & 21 & 22 & 23 & 24 & $25-29$ & $30-34$ & $35-39$ \\
\hline аварцы & 9,4 & 25,4 & 35,1 & 44,6 & 53,5 & 61,7 & 75,9 & 89,7 & 94,4 \\
даргинцы & 9,3 & 26,7 & 36,7 & 48,3 & 56,4 & 64,2 & 79,6 & 92,4 & 96,3 \\
кумыки & 13,2 & 30,5 & 43,0 & 51,7 & 60,7 & 67,3 & 80,0 & 92,0 & 96,0 \\
лакцы & 4,5 & 18,2 & 26,0 & 36,1 & 46,1 & 55,1 & 70,9 & 88,4 & 93,8 \\
лезгины & 9,7 & 29,4 & 39,6 & 50,7 & 60,1 & 68,7 & 80,8 & 91,9 & 95,8 \\
табасаранцы & 17,1 & 41,5 & 53,8 & 58,9 & 69,4 & 76,6 & 85,3 & 93,3 & 96,5 \\
осетины & 4,2 & 14,3 & 19,3 & 26,8 & 36,9 & 44,8 & 59,4 & 76,6 & 83,6 \\
кабардинцы & 9,1 & 24,2 & 32,5 & 40,6 & 47,8 & 55,5 & 69,1 & 83,5 & 90,8 \\
балкарцы & 4,9 & 16,0 & 22,5 & 31,9 & 39,1 & 47,7 & 61,0 & 77,1 & 84,9 \\
карачаевцы & 5,5 & 14,9 & 24,5 & 30,0 & 35,2 & 43,8 & 58,8 & 76,6 & 84,5 \\
черкесы и абазины & 8,3 & 23,9 & 32,8 & 40,8 & 48,2 & 54,9 & 67,4 & 82,3 & 89,5 \\
\hline
\end{tabular}

Источник: Рассчитано авторами по данным ВПН-2010.

Таблица П8. Доли вступивших в первый брак среди мужчин отдельных этносов Северного Кавказа по возрастам, \%

\begin{tabular}{|c|c|c|c|c|c|c|c|c|c|}
\hline \multirow{2}{*}{ Народы } & \multicolumn{9}{|c|}{ Возраст, лет } \\
\hline & 18 & 20 & 21 & 22 & 23 & 24 & $25-29$ & $30-34$ & $35-39$ \\
\hline аварцы & 1,0 & 4,2 & 7,3 & 13,6 & 21,2 & 30,2 & 57,9 & 85,9 & 94,3 \\
\hline даргинцы & 0,9 & 3,8 & 7,6 & 15,4 & 22,7 & 33,3 & 62,1 & 88,9 & 96,2 \\
\hline кумыки & 1,4 & 6,0 & 12,9 & 22,1 & 32,6 & 44,4 & 70,7 & 90,4 & 95,7 \\
\hline лакцы & 0,9 & 3,4 & 5,4 & 13,6 & 20,0 & 27,2 & 52,4 & 81,2 & 91,2 \\
\hline лезгины & 0,9 & 4,7 & 9,1 & 17,1 & 28,0 & 40,2 & 67,8 & 89,5 & 95,2 \\
\hline табасаранцы & 0,9 & 8,1 & 13,5 & 24,4 & 34,9 & 53,3 & 75,5 & 91,7 & 97,5 \\
\hline осетины & 0,6 & 3,4 & 6,3 & 9,7 & 15,2 & 22,2 & 40,7 & 63,3 & 74,8 \\
\hline кабардинцы & 1,2 & 5,4 & 9,1 & 15,9 & 23,1 & 32,3 & 52,5 & 74,8 & 85,2 \\
\hline балкарцы & 0,8 & 2,1 & 4,5 & 9,4 & 13,9 & 22,1 & 41,1 & 63,4 & 77,0 \\
\hline карачаевцы & 1,0 & 5,0 & 7,9 & 10,5 & 15,3 & 20,3 & 36,9 & 59,6 & 74,7 \\
\hline черкесы и абазины & 1,2 & 4,4 & 9,6 & 14,4 & 22,1 & 29,5 & 51,1 & 72,9 & 82,8 \\
\hline
\end{tabular}

Источник: Рассчитано авторами по данным ВПН-2010.

Таблица П9. Расчетные возраста вступления в брак (SMAM) для женщин отдельных этносов Северного Кавказа, лет

\begin{tabular}{|c|c|c|}
\hline Народы & МП-94 & ВПН-2010 \\
\hline аварцы & 23,28 & 24,06 \\
\hline даргинцы & 22,62 & 23,66 \\
\hline кумыки & 22,89 & 23,36 \\
\hline лакцы & 24,22 & 25,03 \\
\hline лезгины & 22,03 & 23,41 \\
\hline табасаранцы & 22,76 & 22,47 \\
\hline осетины & 24,67 & 26,57 \\
\hline кабардинцы & 22,90 & 24,97 \\
\hline балкарцы & 27,13 & 26,27 \\
\hline карачаевцы & 26,38 & 26,55 \\
\hline черкесы и абазины & 22,27 & 25,27 \\
\hline
\end{tabular}

Источник: Рассчитано авторами по данным МП-94 и ВПН-2010. 
Таблица П10. Расчетные возраста вступления в брак (SMAM) для мужчин отдельных этносов Северного Кавказа, лет

\begin{tabular}{|c|c|c|}
\hline Народы & МП-94 & ВПН-2010 \\
\hline аварцы & 25,67 & 27,24 \\
\hline даргинцы & 25,39 & 26,72 \\
\hline кумыки & 25,11 & 25,86 \\
\hline лакцы & 26,66 & 28,01 \\
\hline лезгины & 24,43 & 26,29 \\
\hline табасаранцы & 23,25 & 25,33 \\
\hline осетины & 28,68 & 29,93 \\
\hline кабардинцы & 26,39 & 28,36 \\
\hline балкарцы & 30,48 & 29,11 \\
\hline карачаевцы & 31,01 & 30,71 \\
\hline черкесы и абазины & 26,60 & 28,53 \\
\hline
\end{tabular}

Источник: Рассчитано авторами по данным МП-94 и ВПН-2010.

Таблица П11. Кумулятивные вероятности остаться незамужней к разным возрастам у женщин отдельных этносов Северного Кавказа 1939-48 г.р.

\begin{tabular}{|c|c|c|c|c|c|c|c|}
\hline Возраст, лет & Аварцы & Даргинцы & Кумыки & Лезгины & Карачаевцы & Кабардинцы & Осетины \\
\hline 16 & 0,969 & 0,978 & 0,985 & 0,984 & 0,993 & 0,997 & 0,992 \\
\hline 17 & 0,931 & 0,935 & 0,957 & 0,957 & 0,973 & 0,989 & 0,983 \\
\hline 18 & 0,840 & 0,839 & 0,883 & 0,866 & 0,946 & 0,923 & 0,959 \\
\hline 19 & 0,721 & 0,669 & 0,774 & 0,722 & 0,890 & 0,841 & 0,922 \\
\hline 20 & 0,594 & 0,546 & 0,652 & 0,543 & 0,836 & 0,730 & 0,883 \\
\hline 21 & 0,452 & 0,413 & 0,535 & 0,423 & 0,769 & 0,615 & 0,811 \\
\hline 22 & 0,360 & 0,340 & 0,418 & 0,326 & 0,712 & 0,499 & 0,716 \\
\hline 23 & 0,296 & 0,269 & 0,333 & 0,262 & 0,639 & 0,400 & 0,622 \\
\hline 24 & 0,244 & 0,219 & 0,267 & 0,182 & 0,545 & 0,334 & 0,529 \\
\hline 25 & 0,198 & 0,187 & 0,213 & 0,147 & 0,478 & 0,257 & 0,429 \\
\hline 26 & 0,161 & 0,155 & 0,177 & 0,104 & 0,421 & 0,200 & 0,356 \\
\hline 27 & 0,142 & 0,129 & 0,122 & 0,083 & 0,358 & 0,171 & 0,296 \\
\hline 28 & 0,124 & 0,110 & 0,092 & 0,067 & 0,274 & 0,149 & 0,245 \\
\hline 29 & 0,097 & 0,084 & 0,083 & 0,059 & 0,224 & 0,132 & 0,215 \\
\hline 30 & 0,082 & 0,071 & 0,075 & 0,051 & 0,197 & 0,109 & 0,183 \\
\hline 31 & 0,074 & 0,062 & 0,066 & 0,043 & 0,170 & 0,092 & 0,162 \\
\hline 32 & 0,064 & 0,060 & 0,051 & 0,038 & 0,147 & 0,075 & 0,144 \\
\hline 33 & 0,058 & 0,054 & 0,051 & 0,035 & 0,140 & 0,068 & 0,130 \\
\hline 34 & 0,053 & 0,049 & 0,047 & 0,032 & 0,130 & 0,066 & 0,116 \\
\hline 35 & 0,049 & 0,047 & 0,043 & 0,024 & 0,127 & 0,063 & 0,106 \\
\hline 36 & 0,043 & 0,041 & 0,041 & 0,019 & 0,117 & 0,061 & 0,099 \\
\hline 37 & 0,037 & 0,039 & 0,041 & 0,019 & 0,107 & 0,057 & 0,093 \\
\hline 38 & 0,035 & 0,039 & 0,041 & 0,019 & 0,107 & 0,051 & 0,083 \\
\hline 39 & 0,032 & 0,036 & 0,036 & 0,016 & 0,100 & 0,046 & 0,076 \\
\hline 40 & 0,031 & 0,034 & 0,032 & 0,013 & 0,093 & 0,045 & 0,068 \\
\hline 41 & 0,027 & 0,034 & 0,032 & 0,013 & 0,090 & 0,045 & 0,065 \\
\hline 42 & 0,026 & 0,034 & 0,030 & 0,013 & 0,087 & 0,044 & 0,061 \\
\hline 43 & 0,026 & 0,030 & 0,028 & 0,013 & 0,087 & 0,042 & 0,060 \\
\hline 44 & 0,026 & 0,028 & 0,026 & 0,013 & 0,083 & 0,039 & 0,058 \\
\hline 45 & 0,026 & 0,026 & 0,026 & 0,013 & 0,080 & 0,039 & 0,054 \\
\hline
\end{tabular}

Источник: Рассчитано авторами по данным МП-94. 
Таблица П12. Кумулятивные вероятности остаться неженатым к разным возрастам у мужчин отдельных этносов Северного Кавказа 1939-48 г.р.

\begin{tabular}{|c|c|c|c|c|c|c|c|}
\hline Возраст, лет & Аварцы & Даргинцы & Кумыки & Лезгины & Карачаевцы & Кабардинцы & Осетины \\
\hline 16 & 0,996 & 0,993 & 0,998 & 1,000 & 1,000 & 0,999 & 0,997 \\
\hline 17 & 0,994 & 0,988 & 0,995 & 0,997 & 1,000 & 0,999 & 0,997 \\
\hline 18 & 0,986 & 0,970 & 0,981 & 0,985 & 1,000 & 0,991 & 0,992 \\
\hline 19 & 0,966 & 0,947 & 0,958 & 0,950 & 0,984 & 0,978 & 0,978 \\
\hline 20 & 0,938 & 0,909 & 0,926 & 0,898 & 0,960 & 0,954 & 0,969 \\
\hline 21 & 0,888 & 0,872 & 0,875 & 0,866 & 0,940 & 0,921 & 0,955 \\
\hline 22 & 0,826 & 0,814 & 0,806 & 0,802 & 0,897 & 0,869 & 0,932 \\
\hline 23 & 0,743 & 0,714 & 0,734 & 0,697 & 0,865 & 0,780 & 0,889 \\
\hline 24 & 0,638 & 0,586 & 0,583 & 0,577 & 0,817 & 0,691 & 0,837 \\
\hline 25 & 0,526 & 0,446 & 0,456 & 0,478 & 0,782 & 0,601 & 0,773 \\
\hline 26 & 0,430 & 0,342 & 0,354 & 0,399 & 0,722 & 0,493 & 0,699 \\
\hline 27 & 0,338 & 0,246 & 0,276 & 0,283 & 0,643 & 0,393 & 0,620 \\
\hline 28 & 0,245 & 0,174 & 0,204 & 0,210 & 0,583 & 0,318 & 0,524 \\
\hline 29 & 0,195 & 0,128 & 0,162 & 0,149 & 0,508 & 0,250 & 0,446 \\
\hline 30 & 0,158 & 0,105 & 0,125 & 0,111 & 0,437 & 0,194 & 0,374 \\
\hline 31 & 0,123 & 0,091 & 0,088 & 0,090 & 0,361 & 0,161 & 0,317 \\
\hline 32 & 0,094 & 0,070 & 0,065 & 0,076 & 0,302 & 0,130 & 0,269 \\
\hline 33 & 0,078 & 0,056 & 0,056 & 0,061 & 0,250 & 0,105 & 0,235 \\
\hline 34 & 0,072 & 0,049 & 0,051 & 0,055 & 0,210 & 0,088 & 0,210 \\
\hline 35 & 0,061 & 0,044 & 0,042 & 0,050 & 0,163 & 0,075 & 0,187 \\
\hline 36 & 0,057 & 0,032 & 0,032 & 0,032 & 0,135 & 0,068 & 0,167 \\
\hline 37 & 0,047 & 0,032 & 0,023 & 0,029 & 0,111 & 0,062 & 0,144 \\
\hline 38 & 0,041 & 0,030 & 0,021 & 0,029 & 0,083 & 0,055 & 0,122 \\
\hline 39 & 0,036 & 0,025 & 0,021 & 0,015 & 0,083 & 0,052 & 0,105 \\
\hline 40 & 0,034 & 0,023 & 0,019 & 0,012 & 0,072 & 0,048 & 0,092 \\
\hline 41 & 0,029 & 0,021 & 0,014 & 0,009 & 0,072 & 0,040 & 0,081 \\
\hline 42 & 0,029 & 0,021 & 0,014 & 0,009 & 0,072 & 0,038 & 0,078 \\
\hline 43 & 0,028 & 0,021 & 0,012 & 0,006 & 0,064 & 0,035 & 0,075 \\
\hline 44 & 0,024 & 0,018 & 0,012 & 0,006 & 0,064 & 0,034 & 0,073 \\
\hline 45 & 0,023 & 0,016 & 0,007 & 0,006 & 0,064 & 0,030 & 0,066 \\
\hline
\end{tabular}

Источник: Рассчитано авторами по данным МП-94. 
Таблица П13. Кумулятивные вероятности остаться незамужней к разным возрастам у женщин отдельных этносов Северного Кавказа 1949-58 г.р.

\begin{tabular}{l|c|c|c|c|c|c|c}
\hline Возраст, лет & Аварцы & Даргинцы & Кумыки & Лезгины & Карачаевцы & Кабардинцы & Осетины \\
\hline 16 & 0,980 & 0,984 & 0,990 & 0,986 & 0,974 & 0,998 & 0,988 \\
17 & 0,949 & 0,965 & 0,969 & 0,970 & 0,942 & 0,986 & 0,978 \\
18 & 0,842 & 0,864 & 0,897 & 0,895 & 0,920 & 0,904 & 0,952 \\
19 & 0,698 & 0,684 & 0,774 & 0,733 & 0,851 & 0,773 & 0,899 \\
20 & 0,551 & 0,529 & 0,641 & 0,594 & 0,755 & 0,641 & 0,798 \\
21 & 0,428 & 0,365 & 0,521 & 0,438 & 0,662 & 0,513 & 0,707 \\
22 & 0,331 & 0,282 & 0,397 & 0,333 & 0,559 & 0,418 & 0,606 \\
23 & 0,242 & 0,212 & 0,294 & 0,254 & 0,475 & 0,327 & 0,507 \\
24 & 0,184 & 0,165 & 0,223 & 0,179 & 0,408 & 0,273 & 0,432 \\
25 & 0,144 & 0,136 & 0,177 & 0,144 & 0,350 & 0,227 & 0,362 \\
26 & 0,117 & 0,106 & 0,150 & 0,109 & 0,296 & 0,189 & 0,298 \\
27 & 0,104 & 0,091 & 0,126 & 0,098 & 0,247 & 0,156 & 0,255 \\
28 & 0,088 & 0,083 & 0,113 & 0,084 & 0,207 & 0,134 & 0,211 \\
29 & 0,072 & 0,068 & 0,099 & 0,075 & 0,187 & 0,124 & 0,185 \\
30 & 0,061 & 0,059 & 0,088 & 0,069 & 0,169 & 0,111 & 0,155 \\
31 & 0,053 & 0,049 & 0,078 & 0,059 & 0,153 & 0,101 & 0,145 \\
32 & 0,051 & 0,040 & 0,071 & 0,051 & 0,135 & 0,090 & 0,126 \\
33 & 0,046 & 0,037 & 0,066 & 0,050 & 0,123 & 0,080 & 0,113 \\
34 & 0,043 & 0,034 & 0,064 & 0,046 & 0,117 & 0,075 & 0,104 \\
35 & 0,040 & 0,031 & 0,056 & 0,045 & 0,099 & 0,066 & 0,092 \\
\hline
\end{tabular}

Источник: Рассчитано авторами по данным МП-94.

Таблица П14. Кумулятивные вероятности остаться неженатым к разным возрастам у мужчин отдельных этносов Северного Кавказа 1949-58 г.p.

\begin{tabular}{l|c|c|c|c|c|c|c}
\hline Возраст, лет & Аварцы & Даргинцы & Кумыки & Лезгины & Карачаевцы & Кабардинцы & Осетины \\
\hline 16 & 0,997 & 0,993 & 0,997 & 0,999 & 1,000 & 1,000 & 1,000 \\
17 & 0,994 & 0,992 & 0,993 & 0,996 & 1,000 & 0,999 & 0,999 \\
18 & 0,984 & 0,982 & 0,982 & 0,986 & 1,000 & 0,996 & 0,995 \\
19 & 0,960 & 0,957 & 0,960 & 0,963 & 1,000 & 0,983 & 0,988 \\
20 & 0,923 & 0,914 & 0,914 & 0,928 & 0,981 & 0,957 & 0,973 \\
21 & 0,858 & 0,839 & 0,838 & 0,841 & 0,948 & 0,887 & 0,944 \\
22 & 0,742 & 0,698 & 0,694 & 0,689 & 0,899 & 0,790 & 0,894 \\
23 & 0,589 & 0,533 & 0,544 & 0,531 & 0,831 & 0,653 & 0,830 \\
24 & 0,451 & 0,378 & 0,412 & 0,379 & 0,751 & 0,523 & 0,754 \\
25 & 0,323 & 0,277 & 0,301 & 0,268 & 0,660 & 0,419 & 0,672 \\
26 & 0,245 & 0,200 & 0,216 & 0,190 & 0,573 & 0,309 & 0,589 \\
27 & 0,174 & 0,145 & 0,165 & 0,136 & 0,501 & 0,254 & 0,516 \\
28 & 0,126 & 0,099 & 0,125 & 0,102 & 0,414 & 0,195 & 0,456 \\
29 & 0,095 & 0,083 & 0,100 & 0,075 & 0,357 & 0,157 & 0,388 \\
30 & 0,073 & 0,061 & 0,090 & 0,058 & 0,313 & 0,130 & 0,343 \\
31 & 0,056 & 0,051 & 0,078 & 0,050 & 0,256 & 0,108 & 0,306 \\
32 & 0,043 & 0,044 & 0,062 & 0,040 & 0,216 & 0,097 & 0,272 \\
33 & 0,037 & 0,037 & 0,057 & 0,033 & 0,188 & 0,080 & 0,246 \\
34 & 0,031 & 0,029 & 0,049 & 0,023 & 0,165 & 0,073 & 0,219 \\
35 & 0,025 & 0,028 & 0,040 & 0,019 & 0,155 & 0,067 & 0,195 \\
\hline
\end{tabular}

Источник: Рассчитано авторами по даннымм МП-94. 
Таблица П15. Кумулятивные вероятности остаться незамужней к разным возрастам у женщин отдельных этносов Северного Кавказа 1959-68 г.р.

\begin{tabular}{l|c|c|c|c|c|c|c}
\hline Возраст, лет & Аварцы & Даргинцы & Кумыки & Лезгины & Карачаевцы & Кабардинцы & Осетины \\
\hline 16 & 0,986 & 0,993 & 0,993 & 0,998 & 0,990 & 0,999 & 0,998 \\
17 & 0,965 & 0,980 & 0,977 & 0,988 & 0,982 & 0,993 & 0,988 \\
18 & 0,884 & 0,912 & 0,930 & 0,930 & 0,946 & 0,920 & 0,962 \\
19 & 0,747 & 0,787 & 0,827 & 0,801 & 0,900 & 0,791 & 0,918 \\
20 & 0,611 & 0,641 & 0,692 & 0,654 & 0,824 & 0,654 & 0,830 \\
21 & 0,488 & 0,491 & 0,565 & 0,521 & 0,730 & 0,526 & 0,729 \\
22 & 0,382 & 0,370 & 0,435 & 0,402 & 0,656 & 0,431 & 0,635 \\
23 & 0,310 & 0,291 & 0,345 & 0,307 & 0,574 & 0,345 & 0,538 \\
24 & 0,253 & 0,218 & 0,278 & 0,230 & 0,495 & 0,295 & 0,465 \\
25 & 0,214 & 0,180 & 0,234 & 0,192 & 0,426 & 0,246 & 0,399 \\
\hline
\end{tabular}

Источник: Рассчитано авторами по данным МП-94.

Таблица П16. Кумулятивные вероятности остаться неженатым к разным возрастам у мужчин отдельных этносов Северного Кавказа 1959-68 г.p.

\begin{tabular}{l|c|c|c|c|c|c|c}
\hline Возраст, лет & Аварцы & Даргинцы & Кумыки & Лезгины & Карачаевцы & Кабардинцы & Осетины \\
\hline 16 & 0,997 & 1,000 & 1,000 & 1,000 & 0,998 & 1,000 & 0,999 \\
17 & 0,994 & 0,997 & 1,000 & 0,999 & 0,998 & 0,999 & 0,998 \\
18 & 0,985 & 0,988 & 0,996 & 0,995 & 0,994 & 0,994 & 0,994 \\
19 & 0,974 & 0,971 & 0,982 & 0,986 & 0,986 & 0,984 & 0,992 \\
20 & 0,942 & 0,948 & 0,945 & 0,966 & 0,976 & 0,968 & 0,981 \\
21 & 0,878 & 0,899 & 0,876 & 0,892 & 0,955 & 0,904 & 0,951 \\
22 & 0,775 & 0,769 & 0,746 & 0,756 & 0,917 & 0,809 & 0,898 \\
23 & 0,646 & 0,620 & 0,591 & 0,601 & 0,878 & 0,710 & 0,824 \\
24 & 0,511 & 0,478 & 0,448 & 0,443 & 0,820 & 0,592 & 0,735 \\
25 & 0,407 & 0,361 & 0,346 & 0,318 & 0,761 & 0,501 & 0,649 \\
\hline
\end{tabular}

Источник: Рассчитано авторами по данным МП-94. 


\title{
DEMOGRAPHIC MODERNIZATION AND AGE AT FIRST MARRIAGE OF PEOPLES OF THE NORTH CAUCASUS
}

\author{
KONSTANTIN KAZENIN, EVGENIJ SOROKO
}

\begin{abstract}
The paper studies the dynamics of age at first marriage for indigenous peoples of the North Caucasus from the second half of the 20th through the early 21st century. We focus on interethnic differences in age at first marriage, attempting to assess them at different stages of the social modernization which took place in the North Caucasus from 1960 through the early 2000s and was mainly related to intensive urbanization. Using data from the 1994 Russian Microcensus, we compare the cumulative marriage rate at different ages for men and women of birth cohorts 1939-48, 1949-58 and 1959-68 of eleven peoples of the North Caucasus. It is noted that by the ages reached by two out of three of these cohorts at the time of the Microsensus, similar interethnic contrasts in timing of a first marriage are observed in different cohorts. The same 11 peoples are then compared in terms of the proportion of persons ever married in different age groups at the time of the 2010 Russian Population Census. It is demonstrated that the interethnic differences are nearly the same as for the studied cohorts. Furthermore, comparison of the singulate mean ages at marriage (SMAMs) at the time of the 1994 Microcensus and the 2010 census shows that for most peoples of the North Caucasus the age at marriage became higher, both for men and women, during that period. We conclude that, of the two processes commonly considered as elements of demographic modernization (increasing the age at which one gets married and decreasing inter-ethnic differences based on that age), only the first was actively pursued in the Northern Caucasus during the period under review. Possible explanations of the stability of interethnic differences are considered based on results of field studies.
\end{abstract}

Key words: age at first marriage, cohort analysis, North Caucasus, modernization, interethnic differences.

Konstantin Kazenin (kz@ranepa.ru), The Russian Presidential ACAdEMy of NATIONAL Economy AND PUbLiC ADMINISTRATION, RUSSIA.

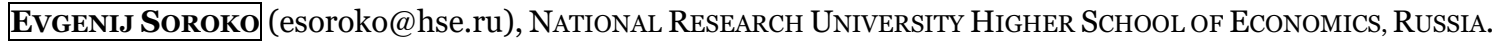

THE ARTICLE REPLIES THE RESULTS OF THE RESEARCH CARRIED OUT BY K. KAZENIN IN THE FRAMEWORK OF THE STATE TASK OF THE RANEPA AND Y. SOROKO IN THE FRAMEWORK OF THE HSE PROGRAM OF FUNDAMENTAL RESEARCH.

DATE RECEIVED : FEBRUARY 2021.

\section{REFERENCES}

Andreev E.M. (2012). O tochnosti rezul'tatov rossiyskikh perepisey naseleniya i stepeni doveriya $\mathrm{k}$ raznym istochnikam informatsii [On the accuracy of the results of Russian population censuses and the level of confidence in different sources of information]. Voprosy statistiki [Statistical issues], 11: 21-35. (In Russ.).

Belozerov V.S. (2005). Ethnicheskaja karta Severnogo Kavkaza [Ethnical map of the North Caucasus]. Moscow: O.G.I. (In Russ.).

Bogojavlenskij D.D. (2012). Perepis 2010: etnicheskij srez [Census 2010: the ethnical aspect]. Demoscope Weekly, 531 - 532. (In Russ.). http://demoscope.ru/weekly/2012/0531/index.php

Carmichael S. (2011). Marriage and power: Age at first marriage and spousal age gap in lesser developed countries. The History of the Family, 16(4), 416-436.

https://doi.org/10.1016/j.hisfam.2011.08.002 
Crul M., Schneider J., Lelie F. (Eds.) (2012). The European second generation compared: does the integration context matter? Amsterdam: Amsterdam university press.

Darskij E.L., Iljina I.P. (2000). Brachnost' v Rossii: analiz tablic brachnosti [Nuptiality in Russia: an analysis of nuptiality tables]. Moscow: Informatika. (In Russ.).

Ediev D.M. (2003). Demograficheskie poteri deportirovannykh narodov SSSR [Demographic losses of deported peoples of the USSR]. Stavropol'. (In Russ.).

Gruber S., Szołtysek M. (2012). Quantifying Patriarchy: An Explorative Comparison of Two Joint Family Societies. MPIDR Working Paper WP 2012-017, April 2012.

Hajnal J (1982). Two kinds of preindustrial household formation systems. Population and Development Review 8(3): 449-494.

Hajnal J. (1953). Age at Marriage and Proportions Marrying. Population Studies, 7, 111-132.

Karpov Ju.Ju. (2001). Zhenskoe prostranstvo v kul'ture narodov Kavkaza [The female sphere in the culture of peoples of the Caucasus]. Saint-Petersburg: Peterburgskoe vostokovedenie. (In Russ.).

Karpov Ju.Ju., Kapustina E.A. (2011). Gorcy posle gor. Migracionnye processy v Dagestane v $X X$-nachale XXI veka: ih social'nye i kul'turnye posledstvija i perspektivy [Mountaineers after mountains. Migration processes in Daghestan in the XX - beginning of the XXI centuries: their social and ethnocultural consequences and perspectives]. Saint-Petersburg: Peterburgskoe Vostkovedenie. (In Russ.).

Kazenin K. (2019b). Migration of population of North Caucasus from the mountains to the valley: challenges of diversity. Zhurnal issledovanij social'noj politiki [Journal of social policy studies], 17(1), 23-38. (In Russ.). https://doi.org/10.17323/727-0634-2019-17-1-23-38

Kazenin K. (2019a). Family traditionalism and age-specific nuptiality patterns: what does the example of Karachay-Cherkessia point to? Demograficheskoe obozrenie [Demographic Review], 6(3), 98-127. (In Russ.). https://doi.org/10.17323/demreview.v6i3.9857

Kazenin K.I., Kozlov V.A. (2016). Rejuvenation of the motherhood in Dagestan: a tendency or an artefact? (The preliminary results of the rural population survey). Demograficheskoe obozrenie [Demographic Review], 3(3), 100-123. (In Russ.). https://doi.org/10.17323/demreview.v3i3.1748

Kazenin K.I., Kozlov V.A. (2017). Osobennosti brachno-reproduktivnogo povedenija naselenija v Respublike Dagestan: ikh prichiny i social'no-ekonomicheskie posledstvija [Special characteristics of nuptiality and fertility in Daghestan: their reasons and social-economic consequences]. Vestnik Instituta ekonomiki RAN [The Bulletin of the Institute for Economics, Russian Academy of Science], 2, 65-81. (In Russ.).

Lerch M. (2013). Patriarchy and fertility in Albania. Demographic Research, 29, 133-166. https://doi.org/10.4054/DemRes.2013.29.6

Mason K.O. (1987). The Impact of Women's Social Position on Fertility in Developing Countries. Sociological Forum, 2(4), 718-745.

Mkrtchyan N.V. (2019). Migracija na Severnom Kavkaze skvoz' prizmu nesovershennoj statistiki [Migration in the Northern Caucasus through the optics of imperfect statistics]. Zhurnal issledovanij social'noj politiki [Journal of social policy studies], 17(1), 7-22. (In Russ.). https://doi.org/10.17323/727-0634-2019-17-1-7-22 
Osmanov A.I. (2000). Agrarnye preobrazovanija v Dagestane i pereselenie gorcev na ravninu $(20-70$-e gody 20 v.) [Agrarian reforms in Daghestan and migration of mountaineers to the valley (1920-1970s)]. Makhachkala. (In Russ.).

Parrado E.A. (2011). How High is Hispanic/Mexican Fertility in the United States? Immigration and Tempo Considerations. Demography, 48(3), 1059-1080. DOI: 10.1007/s13524-0110045-0

Pjankova A.I., Shtsherbakova E.M., Vasin S.A. (2018). Mikroperepisi naselenija Rossii: proshloe, nastojashchee i budushchee [Population microcensuses in Russia: past, present and future]. Demograficheskoe obozrenie [Demographic Review], 5(2), 61-102. (In Russ.). https://doi.org/10.17323/demreview.v5i2.7935

Shakhbanova M.M. (2008). Otnoshenie k mezhnacional'nym brakam v etnicheskom soznanii dagestancev [Attitude to multiethnic marriages in ethnic consciousness of Daghestanians]. Socilogicheskie issledovanija [Sociological studies], 11, 72-76. (In Russ.).

Soroko E.L. (2018). Etnicheskij sostav naselenija i mezhetnicheskie braki v Rossii po dannym perepisej naselenija [Ethnic composition of population and interethnic marriages in Russia according to Censuses' results]. In S.V.Zakharov (Ed.). Naselenie Rossii: dvadcat' chetvertyj ezhegodnyj demograficheskij doklad [Population of Russia: the $24^{\text {th }}$ annual demographic report]. Moscow: Publishing house of Higher School of Economics. (In Russ.).

Starodubrovskaya I.V. (2019). The crisis of the North Caucasian traditional family in the postSoviet period and its social consequences. Zhurnal issledovanij social'noj politiki [Journal of social policy studies], 17(1), 39-56. (In Russ.). https://doi.org/10.17323/727-0634-2019-17$1-39-56$

Szołtysek M. (2008). Three kinds of preindustrial household formation system in historical Eastern Europe: A challenge to spatial patterns of the European family. The History of the Family, 13, 223-257. https://doi.org/10.1016/j.hisfam.2008.05.003

Tajsaev D.M. (2015). Ethnogenez narodov Kavkaza (Ethnogenesis of peoples of the Caucasus). Nal'chik: Izdatel'stvo Kotljarovykh. (In Russ.).

United Nations (1990). Patterns of first marriage. Timing and prevalence. Department of International Economic and Social Affairs. ST/ESA/SER.R/111. New York.

Yavuz S. (2004). Completing the fertility transition: Third birth developments by language groups in Turkey. Demographic Research, 15, 435-460. https://doi.org/10.4054/DemRes.2006.15.15

Zakharov S.V. (2018). Brachnaja struktura naselenija, zakljuchenie i prekrashchenie brakov v Rossii v svete rezul'tatov mikroperepisi naselenija $2015 \mathrm{~g}$. [Marital structure of population, marriage and divorce in Russia in light of results of Microcensus-2015]. In S.V.Zakharov (Ed.). Naselenie Rossii: dvadcat' chetvertyj ezhegodnyj demograficheskij doklad (p. 99-159) [Population of Russia: the $24^{\text {th }}$ annual demographic report]. Moscow: Publishing house of Higher School of Economics. (In Russ.). 